\title{
Re-establishing glacier monitoring in Kyrgyzstan and Uzbekistan, Central Asia
}

\author{
Martin Hoelzle $^{1}$, Erlan Azisov ${ }^{2}$, Martina Barandun ${ }^{1}$, Matthias Huss ${ }^{1,3}$, Daniel Farinotti ${ }^{3,4}$, Abror Gafurov $^{5}$, \\ Wilfried Hagg ${ }^{6}$, Ruslan Kenzhebaev ${ }^{2}$, Marlene Kronenberg ${ }^{1,7}$, Horst Machguth ${ }^{1,8}$, Alexandr Merkushkin ${ }^{10}$, \\ Bolot Moldobekov ${ }^{2}$, Maxim Petrov ${ }^{9}$, Tomas Saks ${ }^{1}$, Nadine Salzmann ${ }^{1}$, Tilo Schöne ${ }^{5}$, Yuri Tarasov ${ }^{10}$, \\ Ryskul Usubaliev $^{2}$, Sergiy Vorogushyn $^{5}$, Andrey Yakovlev ${ }^{11}$, and Michael Zemp ${ }^{8}$ \\ ${ }^{1}$ Department of Geosciences, University of Fribourg, Fribourg, Switzerland \\ ${ }^{2}$ Central Asian Institute for Applied Geosciences, CAIAG, Bishkek, Kyrgyzstan \\ ${ }^{3}$ Laboratory of Hydraulics, Hydrology and Glaciology (VAW), ETH Zurich, Zurich, Switzerland \\ ${ }^{4}$ Swiss Federal Institute for Forest, Snow and Landscape Research WSL, Birmensdorf, Switzerland \\ ${ }^{5}$ GFZ German Research Center for Geosciences, Potsdam, Germany \\ ${ }^{6}$ Department of Geography, University of Munich, Munich, Germany \\ ${ }^{7}$ Meteodat GmbH, Zurich, Switzerland \\ ${ }^{8}$ Department of Geography, University of Zurich, Zurich, Switzerland \\ ${ }^{9}$ Glacial Geology Laboratory, Tashkent, Uzbekistan \\ ${ }^{10}$ NIGMI of UzHydromet, Tashkent, Uzbekistan \\ ${ }^{11}$ Uzbek scientific investigation and design survey institute, UzGIP, Tashkent, Uzbekistan
}

Correspondence to: Martin Hoelzle (martin.hoelzle@unifr.ch)

Received: 10 April 2017 - Discussion started: 15 May 2017

Revised: 26 August 2017 - Accepted: 9 September 2017 - Published: 12 October 2017

\begin{abstract}
Glacier mass loss is among the clearest indicators of atmospheric warming. The observation of these changes is one of the major objectives of the international climate monitoring strategy developed by the Global Climate Observing System (GCOS). Long-term glacier mass balance measurements are furthermore the basis for calibrating and validating models simulating future runoff of glacierised catchments. This is essential for Central Asia, which is one of the driest continental regions of the Northern Hemisphere. In the highly populated regions, water shortage due to decreased glacierisation potentially leads to pronounced political instability, drastic ecological changes and endangered food security. As a consequence of the collapse of the former Soviet Union, however, many valuable glacier monitoring sites in the Tien Shan and Pamir Mountains were abandoned. In recent years, multinational actors have re-established a set of important in situ measuring sites to continue the invaluable long-term data series. This paper introduces the applied monitoring strategy for selected glaciers in the Kyrgyz and Uzbek Tien Shan and Pamir, highlights the existing and the
\end{abstract}

new measurements on these glaciers, and presents an example for how the old and new data can be combined to establish multi-decadal mass balance time series. This is crucial for understanding the impact of climate change on glaciers in this region.

\section{Introduction}

Glacier fluctuations in mountain areas have been monitored in various parts of the world for more than a century (Haeberli et al., 2007; Zemp et al., 2015), and glacier changes are considered to be reliable indicators of worldwide atmospheric warming trends (IPCC, 2013). Mountain glaciers and ice caps are important for early-detection strategies in global climate-related observations. Hence, glaciers are one of the "essential climate variables" (ECVs) in the Global Climate Observing System (GCOS). Embedded in GCOS is the Global Terrestrial Network for Glaciers (GTN-G) operated by the World Glacier Monitoring Service (WGMS), the 
US National Snow and Ice Data Center (NSIDC), and the Global Land Ice Measurements from Space (GLIMS) initiative. These institutions follow the so-called Global Hierarchical Observing Strategy (GHOST) (WMO, 1997b, 2010) forming the basis for the strategic observation framework. The main objectives of long-term glacier monitoring are related to (1) process understanding, (2) model validation and/or calibration, (3) change detection and (4) impact assessment. Furthermore, they play a key role for assessing climate change effects such as estimating sea-level rise, regional changes in runoff and impacts of natural hazards. In particular, countries and regions that are vulnerable to climate change rely on a sound and continuous long-term database providing the necessary information to cope with future challenges in different areas such as water management, irrigation for agriculture, disaster risk reduction and public health.

Continuous in situ monitoring of glaciers in remote areas is a challenging task, and maintaining the necessary measurements can be both logistically and economically demanding. Reasons include missing long-term financial and/or human resources as well as general political instability, access to remote regions, natural hazards or missing infrastructure. In many countries with glacierised mountain ranges, continuous observations are thus lacking. For these reasons, monitoring strategies need to be improved, and different techniques such as in situ measurements, remote sensing and modelling have to be combined to generate high-quality products.

Currently, a re-establishment of historical monitoring sites in Kyrgyzstan and Uzbekistan is jointly being developed by different international projects including Capacity Building and Twinning for Climate Observing Systems (CATCOS), Central Asian Water (CAWa), Cryospheric Climate Services for improved Adaptation (CICADA) or Contribution to High Asia Runoff from Ice and Snow (CHARIS). In the frame of those projects, the measurement series on selected glaciers (see Fig. 1) in Kyrgyzstan and Uzbekistan are (re-)initiated. The project CATCOS had two phases; the first phase was from 2011 to 2013, which was mainly related to the technical installations; and the second phase from 2014 to 2016 was mainly used for capacity building and twinning activities. The project will be continued within the next years in a cooperative effort between Kyrgyzstan, Uzbekistan, Germany and Switzerland.

This paper aims at presenting and discussing the major steps and methodologies developed and applied in Kyrgyzstan and Uzbekistan to (re-)establish glacier monitoring at the most important sites within the two projects CATCOS and CAWa (Fig. 1). The described methods and experience might be a blue print for similar cases in other parts of the world. The key steps, around which this paper is centred, are the (1) collection, homogenisation and securing of historical data; and (2) the re-establishment of glacier monitoring; and (3) capacity building and twinning.

\section{Glaciers in Central Asia}

Glaciers in Central Asia constitute an important water storage component (e.g. Immerzeel et al., 2010; Kaser et al., 2010; Duethmann et al., 2015), which is of particular importance for different sectors including agriculture and energy production (Siegfried et al., 2012). With the ongoing climate change the corresponding variations in glacier area and volume in this region are considerable. Most studies agree on the general trend of glacier mass loss, including an acceleration since the 1970s (e.g. Sorg et al., 2012; Farinotti et al., 2015). Regarding seasonal changes, however, the studies disagree. In their comprehensive review on past changes in highaltitude areas of Central Asian headwaters, Unger-Shayesteh et al. (2013) conclude that there is (i) a lack of reliable data, especially for the glacio-nival zone; (ii) methodological limitation in trend analysis; and (iii) a strong heterogeneity in spatial and temporal extent of the available analyses. These restrictions hamper a sound synthesis for the whole region and limit the understanding of interactions between changes in highly variable climate parameters, the cryosphere and the hydrological response of headwater catchments. Altogether, these shortcomings indicate the importance of high-quality in situ measurements, which are required for a better calibration and validation of local to regional-scale models for estimating future glacier mass balance and runoff.

\subsection{Tien Shan}

Glaciers in the Tien Shan cover around $12400 \mathrm{~km}^{2}$, of which about $7400 \mathrm{~km}^{2}$ is situated in Kyrgyzstan according to the Randolph Glacier Inventory Version 5.0 (RGIv5.0) and about $117 \mathrm{~km}^{2}$ in Uzbekistan (Arendt et al., 2015). In the Tien Shan, only two continuous long-term glacier mass balance series are presently available (Tuyuksu glacier in Kazakhstan and Urumqi Glacier No. 1 in China). Two long-term mass balance measurements in the Kyrgyz Tien Shan were discontinued in the 1990s (Golubin and Karabatkak). Whereas glaciers in the western part of the Tien Shan receive winter accumulation, glaciers in the east are summer-accumulationtype glaciers. Furthermore, annual precipitation sums reach a maximum in the northwest and decrease south-eastwards (Voloshina, 1988). This shift goes along with an alteration of the annual precipitation maximum, which is earlier in the west and in summer in the east (Dyurgerov et al., 1994). Kriegel et al. (2013) show a temperature change of 0.1$0.2^{\circ} \mathrm{C}$ per decade for the ablation period (April-September) during 1960-2007 for the Naryn station. The same authors indicate an unequivocal change in precipitation across a few stations in the central Tien Shan. A decrease in snow cover has been observed for the period from 1960 to 2007 in the entire Tien Shan (Chen et al., 2016). Precipitation changes seem to be less important. Higher air temperatures resulted in positive runoff trends in spring and autumn for the Naryn catchment, which is likely to be related to enhanced snow 


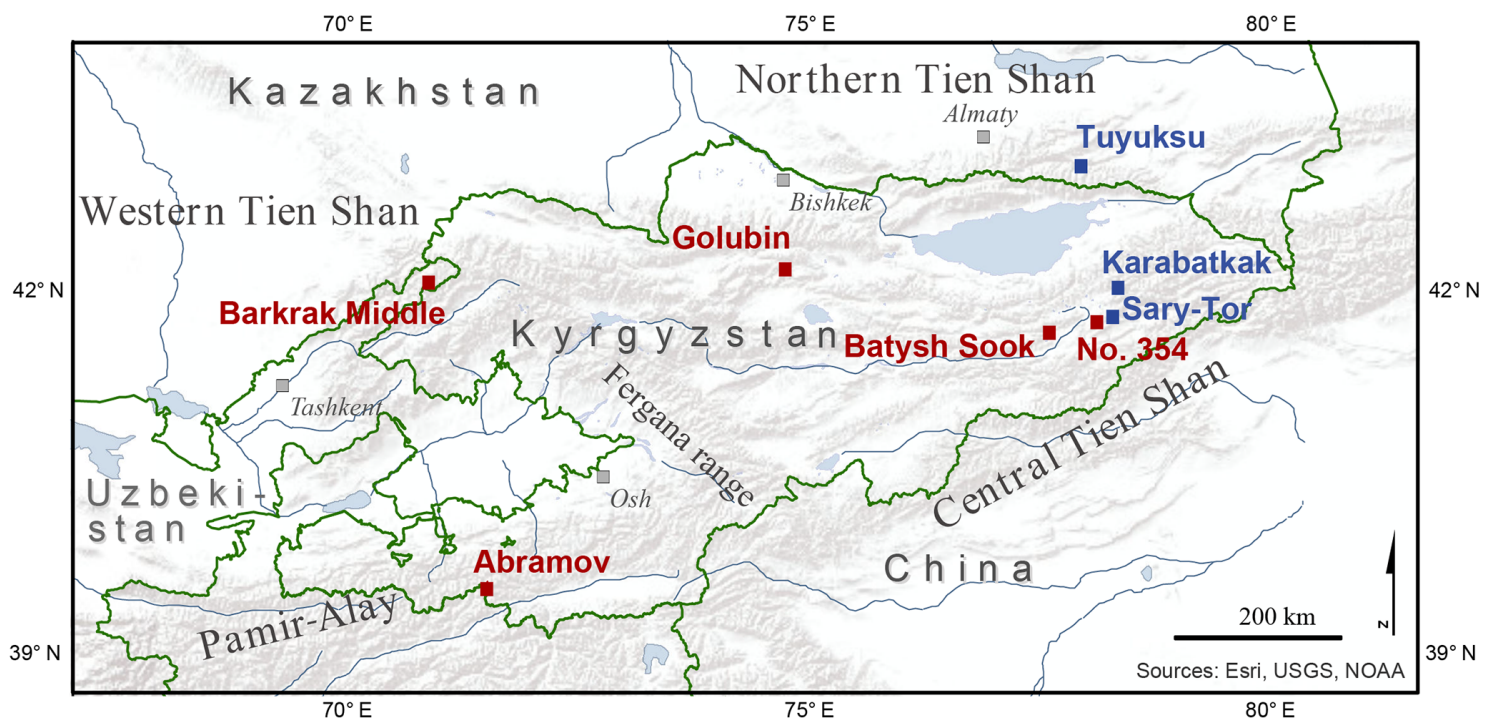

Figure 1. Map of glaciers in Central Asia, where the investigations were gradually re-established starting in 2010. Red symbols show glaciers investigated within the CATCOS and CAWa projects, and blue symbols show glaciers that are covered by other projects such as CHARIS.

and glacier melt corresponding also to the observed annual area shrinkage rates since the middle of the 20th century (e.g. Sorg et al., 2012). For the Small Naryn river, significant negative runoff trends were found, whereas for the Big Naryn river a positive but not significant trend was found for $\mathrm{Au}$ gust, which is the month with the largest glacier runoff contribution (Kriegel et al., 2013).

\subsection{Pamir-Alay}

In the Pamir, glaciers cover approximately $12100 \mathrm{~km}^{2}$. The subregion Pamir-Alay has a total glacier area of around $1850 \mathrm{~km}^{2}$ (both values are based on RGIv5.0). In the PamirAlay, direct mass balance measurements only exist for the Abramov glacier (Fig. 1). For the Pamir-Alay, a strong gradient in the equilibrium line altitude (ELA) from west to east is observed (Glazirin et al., 1993). This is linked to important differences in precipitation (Suslov and Akbarov, 1973). According to Suslov and Akbarov (1973) and Glazirin et al. (1993), the maximum annual precipitation in the Pamir-Alay is about $1900 \mathrm{~mm} \mathrm{a}^{-1}$ in the western part at the border between Kyrgyzstan and Tadjikistan, and about $400 \mathrm{~mm} \mathrm{a}^{-1}$ in the eastern part. The seasonal precipitation regime also differs from west to east: whilst the west shows a maximum precipitation during autumn and winter, the east is characterised by a maximum during spring and summer. Therefore, both accumulation and ablation are region dependent, resulting in different glacier surface mass balance gradients. This also influences total discharge from glaciers, which is estimated as $1.6 \mathrm{~km}^{3} \mathrm{a}^{-1}$, corresponding to about $8 \%$ of the total annual runoff of all rivers in Central Asia (Suslov and Akbarov, 1973). Focusing on a region in the eastern Pamir, Khromova et al. (2006) found a reduction in glacier area of $10 \%$ from
1978 to 1990 and of $9 \%$ from 1990 to 2001 . Glacier front variations with annual rates of $-11.6 \mathrm{~m} \mathrm{a}^{-1}$ for very large glaciers, of $-7.3 \mathrm{~m} \mathrm{a}^{-1}$ for valley glaciers and of $-3.3 \mathrm{~m} \mathrm{a}^{-1}$ for smaller glaciers were observed. The high sensitivity of glaciers to summer temperatures is assumed to be responsible for the long-term retreat (Glazirin et al., 2002). The negative mass budget of the glaciers in this region indicates that increased winter and summer precipitation cannot compensate for the increase in air temperature (Khromova et al., 2006). A smaller reduction in glacier area of $3 \% \mathrm{a}^{-1}$ for the period 2000 and 2007 was observed by Narama et al. (2010) for a region which is close to the southeastern Fergana mountain range situated in the east of the Pamir-Alay.

\section{Instrumentation, methods and data}

\subsection{Monitoring strategy}

The applied strategy to re-establish glacier observation networks in Central Asia is partly based on tiers 2 and 3 of GHOST (WMO, 1997a, b) and the experience gained in different monitoring projects. For glacier mass balance, the strategy is composed of several components:

1. mass balance measurements using the glaciological method;

2. observation of the transient snow line on photographs from terrestrial automatic cameras and/or on satellite images during the summer months; and

3. a mass balance model driven by nearby automatic weather station data, reanalysis data or climate model results (see Fig. 2). 


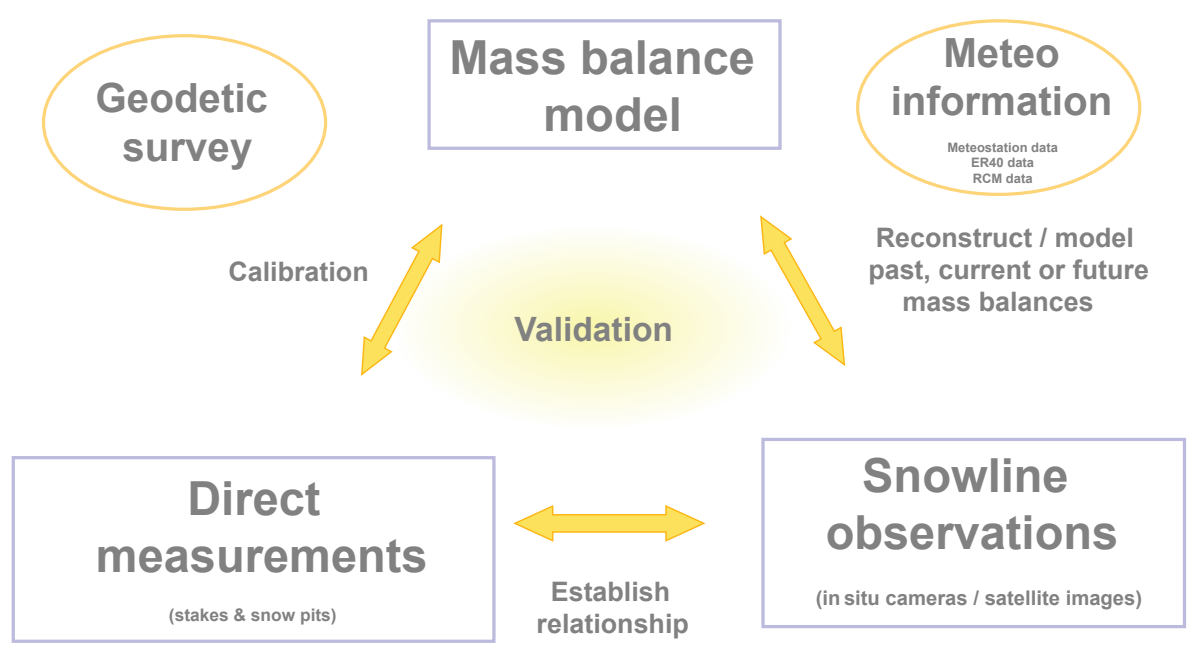

Figure 2. Schematic view of the monitoring strategy applied for re-established measurements in Central Asia.

As an important additional element, geodetic measurements should be integrated for calibration or validation purposes depending on the given objectives. The combination of the different approaches allows producing accurate mass balance estimates with a high temporal and spatial resolution (e.g. Zemp et al., 2013). An important advantage of the described strategy is that all different components can be used independently (e.g. Huss et al., 2009).

The re-establishment of the in situ glacier monitoring has to obey certain criteria for the selection of the glaciers. These are based on several preconditions such as field-site accessibility, availability of historical data, geo-climatic distribution within mountain ranges, suitability for long-term monitoring based on glaciological feasibility and the availability of other measurements. Based on these criteria, the five glaciers Abramov, Golubin, Batysh Sook, Glacier No. 354 and Barkrak Middle were selected within the projects CATCOS and CAWa (see Fig. 1 and Table 1).

\subsection{Implementation}

The implementation of the measurement network within the re-establishing activities (in the following referred to as the "new" measurement network) takes advantage of the concept described above. Our approach is summarised below to clarify the individual steps during the re-establishment of the mass balance series:

1. Finding appropriate collaboration partners.

2. Collection of all historical mass balance data from different sources.

3. Based on a review of these data and expert knowledge, the glacier selection was conducted and accordingly the new mass balance network was designed.
Table 1. Information of observed glaciers and type of measurements currently available from WGMS (2013) for mass balance (mb) and frontal variation (fv), see Fig. 1 for location.

\begin{tabular}{llrrrr}
\hline Glacier & Type & Period & \multicolumn{2}{c}{ Interval } & Re-start \\
\hline Golubin & $\mathrm{mb}$ & 32 & 1968 & 2016 & 2010 \\
Golubin & $\mathrm{fv}$ & 30 & 1861 & 2016 & 2011 \\
Abramov & $\mathrm{mb}$ & 36 & 1967 & 2016 & 2011 \\
Abramov & $\mathrm{fv}$ & 17 & 1850 & 2016 & 2011 \\
Batysh Sook & $\mathrm{mb}$ & 11 & 1970 & 2016 & 2010 \\
Batysh Sook & $\mathrm{fv}$ & 17 & 1975 & 2016 & 2010 \\
Glacier No. 354 & $\mathrm{mb}$ & 6 & 2010 & 2016 & 2010 \\
Glacier No. 354 & $\mathrm{fv}$ & 14 & 1972 & 2016 & 2010 \\
Barkrak Middle & $\mathrm{mb}$ & - & - & - & 2016 \\
Barkrak Middle & $\mathrm{fv}$ & 18 & 1970 & 1990 & 2016 \\
\hline
\end{tabular}

4. Set-up of the new glaciological mass balance measurement networks on the selected glaciers in the years 2010 (Golubin, Batysh Sook, Glacier No. 354), 2011 (Abramov) and 2016 (Barkrak Middle). In parallel, installation of automatic snow line cameras and new weather stations close to the glaciers in collaboration with partners in the CAWa project from Kyrgyzstan, Uzbekistan, Germany and Switzerland.

5. Selection of satellite images with optimal visibility of melt-out patterns and snow lines.

6. A mass balance model was used as an extrapolation tool to obtain from mass balance point measurements the glacier-wide mass balance. Model validation was performed using snow line measurements from the automatic cameras or from satellite images. The model also served for reconstructing mass balance for periods with longer data gaps. 
7. Comparison of mass balance retrieved by in situ measurements and geodetic measurements.

\subsection{Glacier observations}

\subsubsection{Data from WGMS and literature}

Glacier monitoring in Central Asia started more than 60 years ago. During this time, several different glaciological programmes were established in the mountain ranges of Kyrgyzstan, Kazakhstan, Uzbekistan and Tajikistan. We compiled all available glacier data from the WGMS (WGMS, 2013). The total number of past glacier observations are summarised in Table 2, delivering basic information related to all existing measurements having an observation period longer than 2 years. For 17 glaciers, mass balance measurements exist with mean observation period lengths close to 20 years. Thickness change measurements for 9 glaciers and repeated front variation measurements for 62 glaciers with measurement periods from 9 to 20 years are also available. Most of the mass balance measurements were initiated between 1960 and 1970 and were discontinued in the 1990s. Detailed description of stake and snow pit measurements for the Abramov glacier were retrieved from Pertziger (1996).

\subsubsection{Glaciological measurements}

The determination of the mass balance of a glacier using the so-called glaciological method is the standard method used since the earliest times of mass balance measurements (Mercanton, 1916). This robust method is widely used to determine the seasonal to annual mass change of individual glaciers. It is based on measurements of ablation at stakes, which are drilled into the ice of the ablation area, and of snow depth and density measured in snow pits in the accumulation area. The advantage of this method is the direct determination of the temporal evolution of mass balance. Calculation of the total mass change derived from point measurements, however, can be challenging since individual stake readings and snow pit data have to be extrapolated over the glacier, thus resulting in considerable uncertainties (for further details, see Østrem and Brugman, 1991; Kaser et al., 2003; Thibert et al., 2008; Cogley et al., 2011).

On the (re-)established glaciers the following measurements were carried out:

- For the ablation measurements in late summer, plastic or wooden stakes were drilled into the ice in the ablation area to a depth related to the expected melt rate at the corresponding altitude varying on the observed glaciers between around 2 to $10 \mathrm{~m}$. This was done with an auger or a steam drill.

- In the accumulation area, several snow pits were dug to determine the annual snow accumulation and its density. Additionally, several snow depth measurements with
Table 2. Information on glaciers before the re-establishment of the measurements was initiated based on WGMS (2013). Abbreviations: KG, Kyrgyzstan; KZ, Kazakstan; UZ, Uzbekistan; TJ, Tajikistan; mb, mass balance measurements; tc, geodetic thickness change; fv, front variations.

\begin{tabular}{llrrrr}
\hline Country & Meas. & $\begin{array}{r}\text { Glaciers } \\
\text { observed }\end{array}$ & $\begin{array}{r}\text { Mean } \\
\text { observation } \\
\text { period }\end{array}$ & $\begin{array}{r}\text { Mean } \\
\text { start } \\
\text { date }\end{array}$ & $\begin{array}{r}\text { Mean } \\
\text { end } \\
\text { date }\end{array}$ \\
\hline KG & mb & 7 & 19 & 1973 & 1994 \\
KG & tc & 2 & 2 & 1977 & 1989 \\
KG & fv & 19 & 9 & 1954 & 2002 \\
KZ & mb & 9 & 19 & 1974 & 1992 \\
KZ & tc & 7 & 2 & 1958 & 1998 \\
KZ & fv & 11 & 16 & 1957 & 1987 \\
UZ & mb & 0 & & & \\
UZ & tc & 0 & & & \\
UZ & fv & 11 & 20 & 1965 & 1988 \\
TJ & mb & 1 & 3 & 1983 & 1985 \\
TJ & tc & 0 & & & \\
TJ & fv & 21 & 11 & 1968 & 1989 \\
\hline
\end{tabular}

steel or aluminium rods of 2 to $5 \mathrm{~m}$ length were performed. Theses were combined with occasional groundpenetrating radar (GPR) measurements using a frequency of $800 \mathrm{MHz}$ to detect snow layers of former years. This information allows an improved extrapolation of the highly variable snow distribution on the glacier (Sold et al., 2013) and reconstructing past accumulation rates back to almost one decade (Sold et al., 2015).

- Frontal variations in glacier length were measured at the glacier tongue using handheld GPS and/or were digitised based on satellite images.

The stake and snow pit locations aim at representing the former transects of measurement on the glaciers to allow comparability. The total number of new stakes and pits, however, had to be reduced substantially to keep the annual work load on a manageable level.

\subsubsection{Geodetic mass balance}

Geodetic mass balance measurements are useful to infer mass and volume changes of glaciers over decadal periods (Ahlmann, 1924), providing considerable precision and high spatial resolution. Digital elevation models (DEMs) derived from different sources such as topographic maps, GPS surveys, aerial photographs, satellite images, synthetic-aperture radar or Light Detection and Ranging (LiDAR) are compared to each other, and the elevation differences over the glacier can be converted into the glacier's mass change over a given time interval (e.g. Bauder et al., 2007; Thibert and Vincent, 2009; Zemp et al., 2013). In general, multi-annual time periods are needed to reach an acceptable level of accuracy (Paul 
et al., 2013). The most important uncertainties are due to (i) density conversion (Huss, 2013), (ii) elevation biases and errors in the co-registration of the two DEMs (Berthier et al., 2006; Paul, 2008; Nuth and Kääb, 2011), (iii) data gaps, (Pieczonka et al., 2011; Bolch and Buchroithner, 2008), and (iv) errors and artefacts in the DEMs.

Geodetic glacier volume changes focusing on Central Asia often rely on the Shuttle Radar Topography Mission (SRTM) as a baseline for the year 2000 (e.g. Berthier et al., 2010; Gardelle et al., 2012, 2013; Surazakov and Aizen, 2006). However, the quality of the SRTM DEM is affected by electromagnetic wave penetration into the snow and ice. This can lead to major uncertainties, especially affecting elevation changes in the accumulation area, for which corrections have to be applied (Berthier et al., 2006; Gardelle et al., 2012, 2013; Kääb et al., 2015) These corrections, however, are difficult to quantify as they strongly vary with local conditions (Kääb et al., 2015). Other data sources for the geodetic method applied in Central Asia are topographic maps or stereo imagery derived from several sensors operating in the visible range of the spectrum, such as ASTER (Advanced Spaceborne Thermal Emission and Reflection Radiometer), SPOT (Satellite pour l'observation de la Terre), Cartosat, Corona or Hexagon data (e.g. Hagg et al., 2004; Bolch et al., 2011, 2012; Pieczonka et al., 2013; Gardelle et al., 2013; Pieczonka and Bolch, 2015; Bolch, 2015; Petrakov et al., 2016). Furthermore, laser altimetry measurements, e.g. from the ICESat satellite mission operated between 2003 and 2009, offer a possibility of mass change computation for mountain glaciers (Kääb et al., 2012; Gardner et al., 2013; Neckel et al., 2014; Farinotti et al., 2015). Elevation differences at points along the repeated tracks are interpolated and converted into volume and mass changes. Due to point measurements and uncertainties associated with interpolation, this method instead delivers robust results on large scales and not for individual glaciers.

\subsubsection{Snow line observations}

The calculation of glacier-wide annual mass balance from statistical relations using ELA and accumulation area ratio (AAR) is well established (Braithwaite and Müller, 1980; Braithwaite, 1984; Benn and Lehmkuhl, 2000; Kulkarni, 1992). It has been applied in many different mountain ranges (Kulkarni, 1992; Rabatel et al., 2008; Chinn et al., 2012; Stumm, 2011), and it is often used to relate temperature and precipitation with mass balance (Kuhn, 1984; Ohmura et al., 1992). Generally, ELA and the annual mass balance are well correlated (Rabatel et al., 2005, 2012). The advantage of using ELA and AAR is their straightforward mapping using remote sensing data (Rabatel et al., 2013). However, this approach relies on the calibration against long-term glaciological in situ measurements. An interesting alternative is the use of transient snow lines. Their monitoring can be used as a good proxy for the sub-seasonal mass balance (Huss et al.,
2013). The distinction between snow-covered and snow-free zones on a glacier can be retrieved by different means such as analysis of repeated images taken by terrestrial cameras and satellites, or by mapping with GPS. This information can be used to establish and analyse snow-cover depletion curves (e.g. Parajka et al., 2012), and, in combination with corresponding model approaches, the water equivalent of the winter snow cover can be directly extracted (e.g. Martinec and Rango, 1981; Schaper et al., 1999). Repeated snow line observations during the ablation period are also used for mass balance model validation (Kenzhebaev et al., 2017; Barandun et al., 2015; Kronenberg et al., 2016).

The annual course of the snow line, and the related snowcovered area fraction, was recently used in combination with a backward modelling approach to determine sub-seasonal mass balance values (Hulth et al., 2013; Huss et al., 2013). The approach by Huss et al. (2013) uses transient snow line observations and meteorological information in combination with a mass balance model. Remote monitoring for glaciers with limited accessibility is thus possible. It also offers an important backup that helps to achieve a better coverage with mass balance estimates and thus to reduce future data gaps.

In the framework of the CATCOS project, we installed six terrestrial cameras (Mobotix, M15 and M25) for snow line observation: two cameras at the Abramov glacier, two cameras at the Golubin glacier, one camera at Glacier No. 354 and one camera at the Barkrak Middle glacier. Every day, eight pictures are taken, transferred to a nearby CAWa meteorological station, and sent via satellite connection to a database (Schöne et al., 2013). For Glacier No. 354 (Kyrgyzstan) and the Barkrak Middle glacier (Uzbekistan), data are stored locally and downloaded once a year.

\subsubsection{Meteorological measurements}

Meteorological data constitute an important component of a complete glacier monitoring approach as a required input to mass balance models. There has been an extensive network of continuous long-term meteorological time series of air temperature and precipitation in Central Asian countries during the Soviet Union times (Aizen et al., 1995b). However, this network thinned out considerably during the recent past (Unger-Shayesteh et al., 2013).

Some new meteorological stations were installed in the close vicinity of the Abramov glacier in 2011 and the Golubin glacier in 2013 by the CAWa project (Schöne et al., 2013). These two stations were equipped with standard meteorological and ground sensors (see detailed description in Schöne et al., 2013). Data access is open and facilitated by GeoForschungsZentrum (GFZ) in Potsdam and CAIAG in Kyrgyzstan (http://sdss.caiag.kg). Meteorological information for the glaciers Batysh Sook and Glacier No. 354 is retrieved from the nearby Tien Shan meteorological station ( $3660 \mathrm{~m}$ a.s.1.). This station has been operational since 1930 but was relocated in 1997. This causes a shift in the 
data, hampering its use for long-term studies. Data are available from the National Hydrometeorological Service of Kyrgyzstan. A small meteorological station was installed in the glacier forefield of the Barkrak Middle glacier in 2016 by the CATCOS project.

The access to several historical meteorological time series is, for example, provided by the Northern Eurasia Earth Science Partnership Initiative (NEESPI). Datasets such as reanalysis products - e.g. NCEP-NCAR R1 (US National Centers for Environmental Prediction-US National Center for Atmospheric Research), ERA-Interim (European Centre for Medium-Range Weather Forecasts Reanalysis) or MERRA (Modern-Era Retrospective Analysis for Research and Applications) can be used to fill data gaps and to extend data records back in time (e.g. Salzmann et al., 2013; Schär et al., 2004; Schienmann et al., 2008; Schmidli et al., 2001).

\subsubsection{Establishing multi-decadal mass balance series}

The combination of the methods described in the above chapters allows fully exploiting the richness of the available data. Our approach is visualised schematically in Fig. 2, and an example is shown in Fig. 4. Establishing multi-decadal mass balance series for data-scarce regions or time periods requires various data sources to be combined in an optimal way. The methodology that has been presented already in different studies (e.g. Barandun et al., 2015; Kronenberg et al., 2016; Kenzhebaev et al., 2017) is shortly summarised hereafter.

The core of the establishment of long-term mass balance series is made up of in situ data (stake and snow pit measurements and meteorological information, such as precipitation and temperature), a mass balance model, and remote sensing products such as optical satellite sensors and terrestrial cameras. The model used can either be a simple degree day or a more sophisticated energy balance model, which is able to produce sub-seasonal mass balance as an output (e.g. Machguth et al., 2006; Huss et al., 2008, 2009). Depending on the objective of the application, different investigations are possible with the ingredients of the strategy presented in Fig. 2. In Barandun et al. (2015, for details), for example, we reanalysed mass balance data from the period 1968-1994 and calculated glacier-wide balances for the years without measurements to establish a continuous series covering the period 1968-2014 using a spatially distributed simple energy balance model (Fig. 4). The model was calibrated with seasonal mass balance data and was subsequently used to reconstruct the mass balance for the period with no measurements. Model validation was performed by using snow line observations derived from optical satellite images and, when available, also from images of an automatic camera. In a final step, the resulting mass balance values covering several years or decades were compared to the geodetic glacier volume change determined based on the comparison of digital elevation models (Barandun et al., 2015).

\section{Investigations at individual monitoring sites}

In the recent past, results of glacier monitoring activities in Central Asia (except Kazhakstan and China) are mainly based on remote sensing techniques with a focus on geodetic area and volume change assessments (see Table 4) or front variation measurements (Aizen et al., 2007; Konovalov and Desinov, 2007; Niederer et al., 2007; Haritashya et al., 2009; Kääb et al., 2015; Narama et al., 2010; Hagg et al., 2013; Kriegel et al., 2013; Gardelle et al., 2013; Gardner et al., 2013; Ozmonov et al., 2013; Pieczonka et al., 2013; Khromova et al., 2014; Bolch, 2015; Pieczonka and Bolch, 2015; Farinotti et al., 2015; Petrakov et al., 2016). Between 1994 and 1998, most of the in situ glacier observation programmes were discontinued. The re-initiation of in situ monitoring activities on five selected glaciers - Abramov, Golubin, Batysh Sook, Glacier No. 354 and Barkrak Middle - now continues the historical measurement series and is described in the following sections, with the main findings emerging from the current and historical monitoring. At some other glaciers, such as Karabatkak or Sary-Tor, a re-establishment programme was also developed under the auspices of the Kyrgyz Institute of Water Problem and Hydropower Engineering together with the Moscow State University within the project CHARIS financed by USAID.

\subsection{Abramov glacier, Kyrgyzstan}

The Abramov glacier is a valley-type glacier and is located in the northern slope of Pamir-Alay (Kyrgyzstan) within the basin of the Vakhsh River, which is one of the largest tributaries of the Amu Darya river (Fig. 1). The glacier drains into the Koksu River, which has a hydrological catchment area of $58 \mathrm{~km}^{2}$ with a glacierisation of roughly $51 \%$ (Hagg et al., 2006). Abramov has a surface area of about $24 \mathrm{~km}^{2}$ (in 2013) and a volume of $2.54 \mathrm{~km}^{3}$ (Huss and Farinotti, 2012). The glacier is exposed to the north and ranges from about 3600 to 5000 ma.s.l.

Annual mean air temperature at the equilibrium line of the glacier (around $4260 \mathrm{~m}$ a.s.1.) is -6.5 to $-8{ }^{\circ} \mathrm{C}$ (Kamnyansky, 2001). Average annual precipitation measured at $3837 \mathrm{ma}$ a.s.l. is about $750 \mathrm{~mm}$ (Glazirin et al., 1993). The glacier is assumed to have a temperate accumulation zone with cold ice near the surface in the ablation area, even though slightly negative temperatures were reported in the accumulation area by Kislov et al. (1977).

A research station at the Abramov glacier was built in 1967 by the Central Asian Hydrometeorological Institute (SANIGMI) in Tashkent, guaranteeing the continuous collection of glaciological and meteorological observations. The station was destroyed in the late 1990s during politically unstable times (Fig. 3). With the station, other valuable equipment and the measurement network were also lost.

Continuous and detailed mass balance measurements exist from 1968 to 1994 (Pertziger, 1996), whereas from 

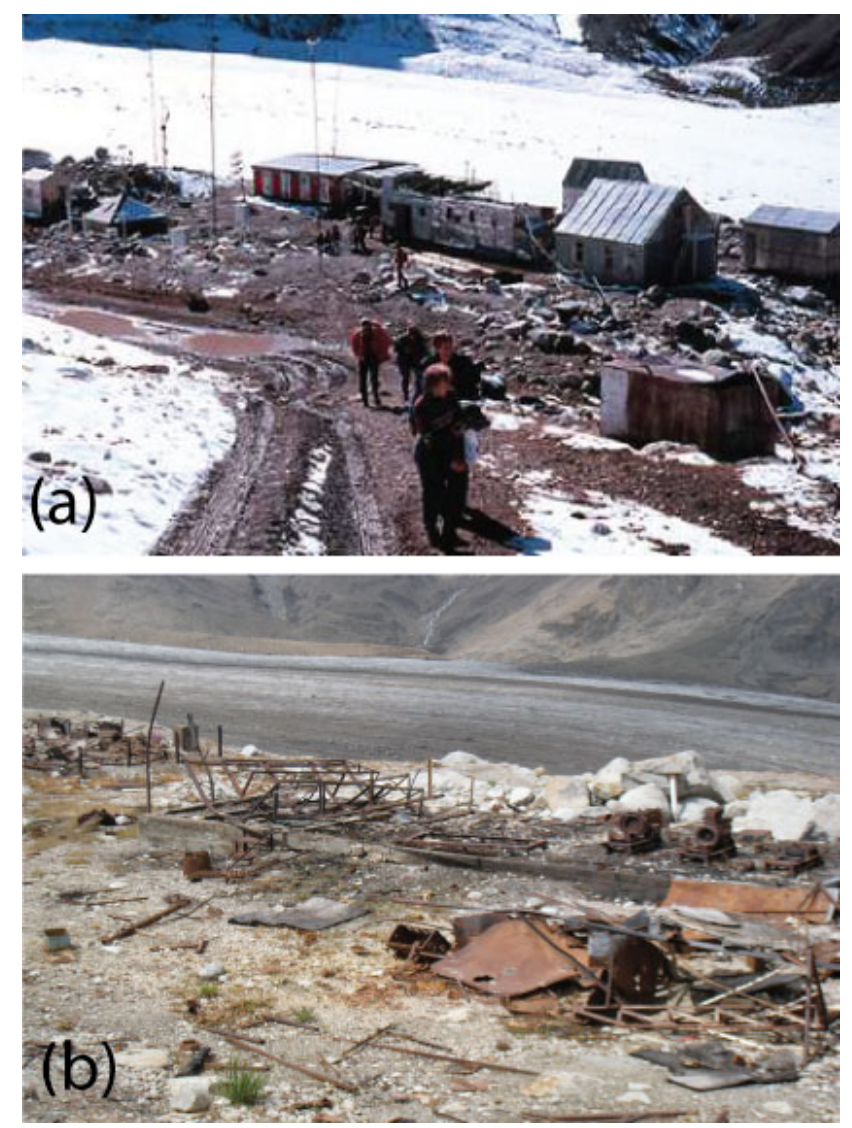

Figure 3. (a) Abramov research station in the year 1993 (photo: NSIDC); (b) ruins of the Abramov research station in 2011 (photo: M. Hoelzle).

1994 to 1998 seasonal mass balance values are available from WGMS (2001). Several publications have assessed the long-term mass balance of the Abramov glacier. Comparing the results of these studies, differences on the order

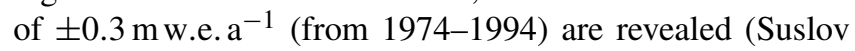
and Krenke, 1980; Glazirin et al., 1993; Kamnyansky, 2001; Pertziger, 1996; WGMS, 2001; Dyurgerov, 2002; Barandun et al., 2015). Therefore, the data series were homogenised (Barandun et al., 2015). The historic mass balance measurements on the Abramov glacier only show few positive years with mass balances exceeding +0.3 mw.e. $\mathrm{a}^{-1}$, such as 1968-1969, 1971-1972, 1986-1987, 1991-1992 and 1992-1993. Rasmussen (2013) calculated the Abramov glacier's mass balance sensitivity to air temperature change as $-0.47 \mathrm{~m}$ w.e. $\mathrm{a}^{-1}{ }^{\circ} \mathrm{C}^{-1}$ using a positive degree-day model driven with NCEP-NCAR Reanalysis data, indicating the highest sensitivity of all studied glaciers in Central Asia.

The mass balance was reconstructed according to the method described in Sect. 3.3.6 and for the time period for which no direct measurements were available (Barandun et al., 2015). Such reconstructions of past mass balance time series are important to (a) fill data gaps, (b) com-
Table 3. Glaciological mass balance for Abramov, Golubin, Batysh Sook and Glacier No. 354 after the re-establishment of the measurements, calculated for the hydrological year using a mass balance model.

\begin{tabular}{lrrrr}
\hline Glacier & Year & $\begin{array}{r}\text { Area } \\
\left(\mathrm{km}^{2}\right)\end{array}$ & $\begin{array}{r}\text { ELA } \\
(\mathrm{m} \text { a.s.l. })\end{array}$ & $\begin{array}{r}\mathrm{B}_{\mathrm{a}} \\
\left(\mathrm{m} \mathrm{w.e.} \mathrm{a}^{-1}\right)\end{array}$ \\
\hline Abramov & $2011 / 2012$ & 24.06 & 4265 & $-0.795 \pm 0.30$ \\
Abramov & $2012 / 2013$ & 24.01 & 4225 & $-0.436 \pm 0.34$ \\
Abramov & $2013 / 2014$ & 24.01 & 4245 & $-0.730 \pm 0.10$ \\
Abramov & $2014 / 2015$ & 23.94 & 4115 & $+0.171 \pm 0.30$ \\
Abramov & $2015 / 2016$ & 23.93 & 4185 & $-0.274 \pm 0.30$ \\
\hline Golubin & $2010 / 2011$ & 5.47 & 3775 & $+0.029 \pm 0.2$ \\
Golubin & $2011 / 2012$ & 5.47 & 3875 & $-0.318 \pm 0.2$ \\
Golubin & $2012 / 2013$ & 5.45 & 3835 & $-0.251 \pm 0.2$ \\
Golubin & $2013 / 2014$ & 5.45 & 4325 & $-0.665 \pm 0.2$ \\
Golubin & $2014 / 2015$ & 5.44 & 4315 & $-0.565 \pm 0.2$ \\
Golubin & $2015 / 2016$ & 5.44 & 3745 & $+0.130 \pm 0.2$ \\
\hline Batysh Sook & $2010 / 2011$ & 1.13 & 4255 & $-0.375 \pm 0.17$ \\
Batysh Sook & $2011 / 2012$ & 1.13 & 4265 & $-0.476 \pm 0.15$ \\
Batysh Sook & $2012 / 2013$ & 1.12 & 4255 & $-0.368 \pm 0.16$ \\
Batysh Sook & $2013 / 2014$ & 1.11 & 4265 & $-0.463 \pm 0.16$ \\
Batysh Sook & $2014 / 2015$ & 1.11 & 4305 & $-0.822 \pm 0.15$ \\
Batysh Sook & $2015 / 2016$ & 1.11 & 4265 & $-0.424 \pm 0.14$ \\
\hline Glacier No. 354 & $2010 / 2011$ & 6.47 & 4195 & $-0.41 \pm 0.24$ \\
Glacier No. 354 & $2011 / 2012$ & 6.44 & 4205 & $-0.46 \pm 0.26$ \\
Glacier No. 354 & $2012 / 2013$ & 6.42 & 4225 & $-0.55 \pm 0.25$ \\
Glacier No. 354 & $2013 / 2014$ & 6.41 & 4275 & $-0.64 \pm 0.22$ \\
Glacier No. 354 & $2014 / 2015$ & 6.41 & 4365 & $-0.84 \pm 0.24$ \\
Glacier No. 354 & $2015 / 2016$ & 6.40 & 4155 & $-0.23 \pm 0.24$ \\
\hline
\end{tabular}

pare past variabilities with current ones, (c) detect changes in glacier sensitivity, and (d) interpret present and future impacts of glacier change. An example of such a reconstruction is shown in Fig. 4 for the Abramov glacier (Barandun et al., 2015), where mass balance data was homogenised for the period 1968-1998 and 2012-2015 and reconstructed for the period 1999-2011 using a calibrated distributed mass balance model. The results of the reconstruction were validated using snow lines digitised from the Landsat images. The mean mass balance for the time period 1998-2011 is $-0.51 \pm 0.17 \mathrm{~m}$ w.e. $\mathrm{a}^{-1}$, and it is $-0.44 \pm 0.10 \mathrm{~m}$ w.e. $\mathrm{a}^{-1}$ for 1968-2014 (Barandun et al., 2015).

Maximal discharge of the Abramov glacier has been measured in the month of August, with around $14 \mathrm{~m}^{3} \mathrm{~s}^{-1}$ during the first observation years starting in 1967 until the beginning of the 1970s (Yemelyanov, 1973). Following Hagg et al. (2007) the discharge patterns will change according to different climate scenarios indicating an increase in annual runoff, and, furthermore, the seasonal peak runoff will shift towards May to June, and a decrease will likely occur in August. Compared to the very high sensitivity of glacial runoff to air temperature, precipitation changes appear to be of secondary importance (Hagg et al., 2007).

A new and fully automated meteorological station was installed in August 2011 at the Abramov glacier at an alti- 


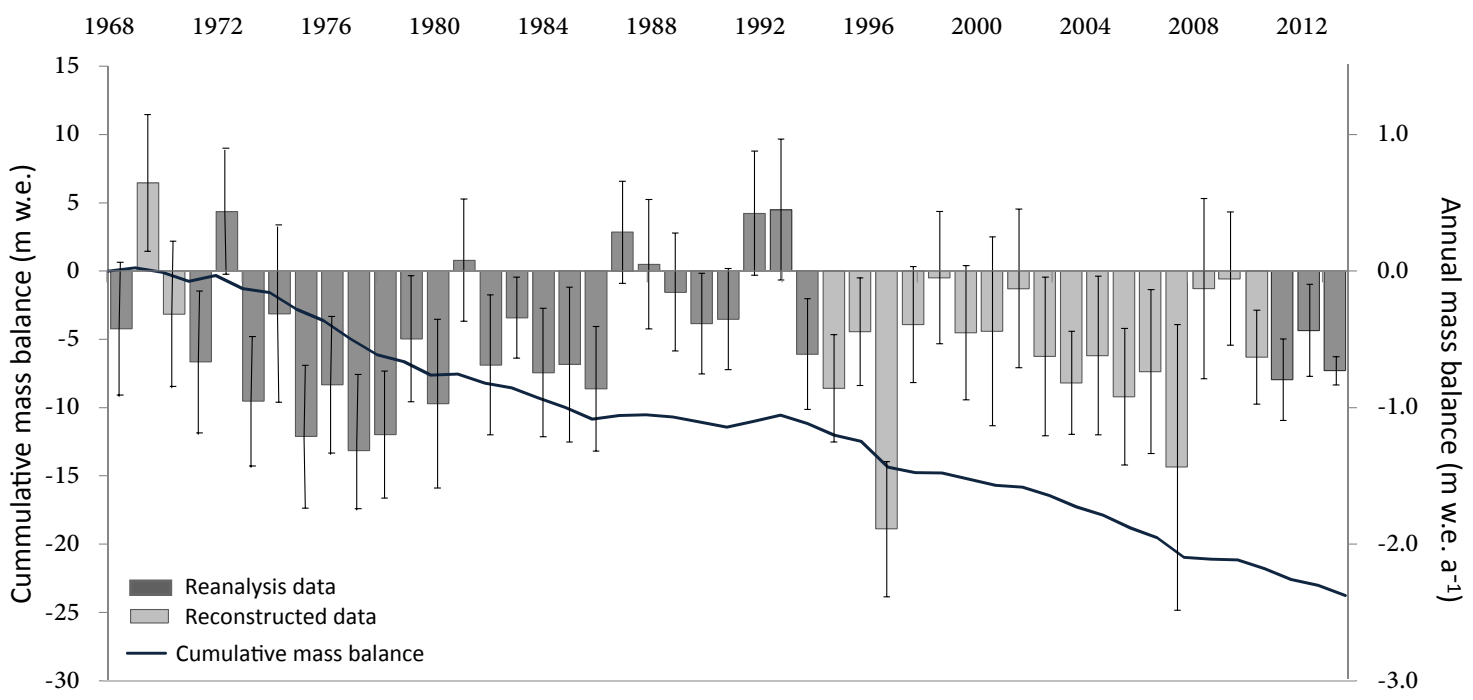

Figure 4. Reconstructed mass balance data for the Abramov glacier according to Barandun et al. (2015).

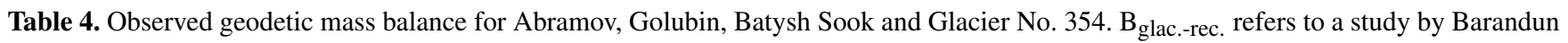
et al. (2015), where the mass balance was reconstructed based on a calibrated model (see Sect. 3.3.6).

\begin{tabular}{|c|c|c|c|c|}
\hline Glacier & Method & Source & Period & $\begin{array}{r}\mathrm{B}_{\mathrm{a}} \\
\left(\mathrm{m} \text { w.e. } \mathrm{a}^{-1}\right)\end{array}$ \\
\hline Abramov & $\mathrm{B}_{\text {glac.-rec. }}$ & Barandun et al. (2015) & $2000-2011$ & $-0.51 \pm 0.15$ \\
\hline Abramov & B geod. & Gardelle et al. (2013) & 2000-2011 & $-0.03 \pm 0.14$ \\
\hline Golubin & $\mathrm{B}_{\text {geod. }}$ & Bolch (2015) & 1964-1999 & $-0.46 \pm 0.24$ \\
\hline Golubin & $B_{\text {geod. }}$ & Bolch (2015) & 1999-2012 & $-0.28 \pm 0.97$ \\
\hline Glacier No. 354 & $\mathrm{~B}_{\text {geod. }}$ & Pieczonka and Bolch (2015) & 1975-1999 & $-0.79 \pm 0.25$ \\
\hline Glacier No. 354 & $\mathrm{~B}_{\text {geod. }}$ & Kronenberg et al. (2016) & 2003-2012 & $-0.48 \pm 0.07$ \\
\hline
\end{tabular}

tude of $4100 \mathrm{ma}$ a.s.l. within a distance of about $1 \mathrm{~km}$ from the glacier. The station records GPS position, air temperature, relative humidity, atmospheric pressure, precipitation, wind speed and direction, and shortwave incoming and outgoing radiation, as well as longwave incoming and outgoing radiation, soil water content and soil temperatures (Schöne et al., 2013). The historical and re-established mass balance networks are shown in Fig. 5. Field data were analysed by using a distributed mass balance model for extrapolating the point measurements to the entire glacier (Huss et al., 2009; Barandun et al., 2015), and the results are presented in Table 3. Since 2011, five field campaigns were conducted on the Abramov glacier, allowing the calculation of glacier-wide mass balance (see Fig. 6). Annual mass balance 2012-2016, i.e. after the re-establishing of the monitoring programme, was negative, with a mean of $0.41 \mathrm{~m}$ w.e. $\mathrm{a}^{-1}$ (Table 3 ). The observed cumulative glacier frontal retreat since 1850 sums up to more than $2 \mathrm{~km}$ (see Table 5, Fig. 7).

\subsection{Golubin glacier, Kyrgyzstan}

The Golubin glacier is situated in the Ala-Archa catchment located in the Kyrgyz Ala-Too range in the northern Tien Shan in Kyrgyzstan (Fig. 1). The catchment belongs to the larger Chu River basin, which drains into the Kazakh steppe. The Ala-Archa catchment contains 48 glaciers. Bolch (2015) reports a total glaciated area in Ala-Archa of $40.5 \pm 0.5 \mathrm{~km}^{2}$ in 1964 and $33.3 \pm 0.8 \mathrm{~km}^{2}$ in 2010. The Golubin glacier covers an area of $5.5 \mathrm{~km}^{2}$, based on a satellite image of 2002 , has a volume of $0.348 \mathrm{~km}^{3}$ (Huss and Farinotti, 2012) and spans over an altitudinal range of 3300 to 4400 ma.s.l. The continental-type glacier has a northern aspect in the accumulation area and a northwestern aspect in the ablation area.

The climate in the Ala-Archa region is characterised by limited annual precipitation of around $700 \mathrm{~mm} \mathrm{a}^{-1}$ mainly during April to June (48\%) (Aizen et al., 2006). Mean annual air temperature in the ablation area of the glacier ( 3450 ma.s.l.) is about $1.5^{\circ} \mathrm{C}$, calculated with a lapse rate of $0.72{ }^{\circ} \mathrm{C}$ per $100 \mathrm{~m}$ from Baitik station (Aizen et al., 1995a). 


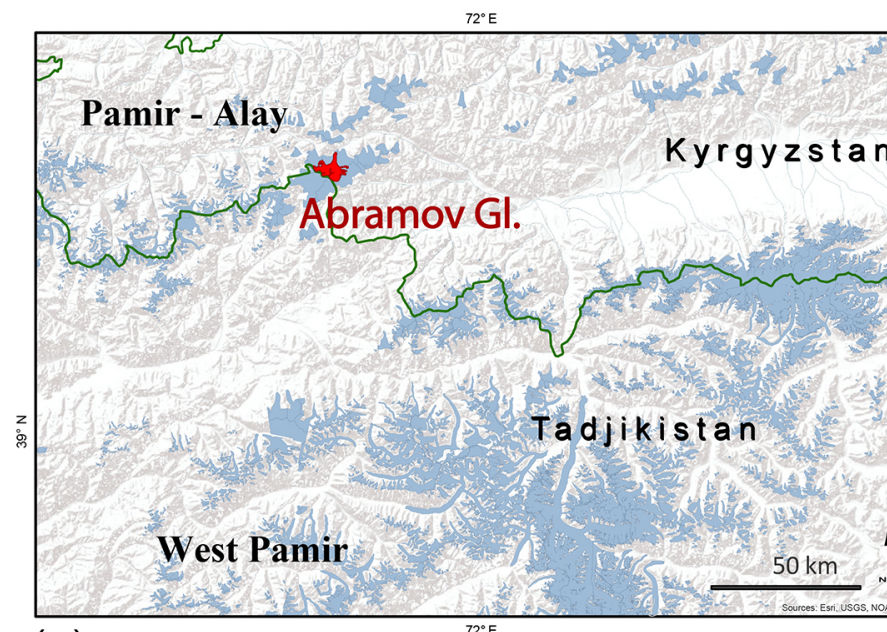

(a)

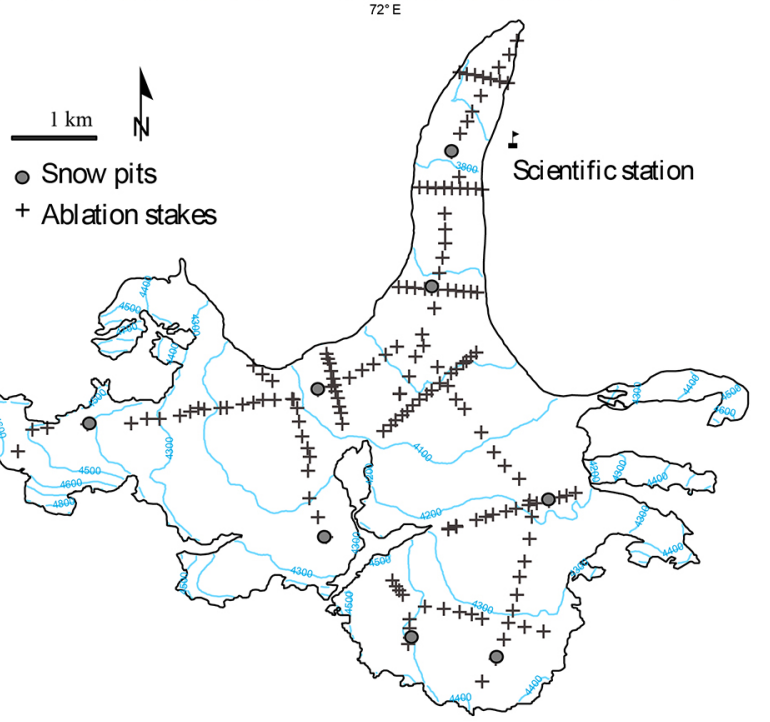

Figure 5. Historical (c) and new (d) mass balance network on the Abramov glacier (Kyrgyzstan) with corresponding (overview) map (a) and snow line camera picture (b).

Glaciological investigations on the Golubin glacier started in 1958 and continued until 1994, when the monitoring programme was stopped (see Table 1). Between 1958 and 1973, the mass balance was predominantly positive and mainly negative afterwards (Aizen, 1988). Using imagery of several satellites Bolch (2015) determined the geodetic mass change for the periods 1964 to 1999 and 1999 to 2010 . A mass balance of $-0.46 \pm 0.24 \mathrm{mw}$.e. $\mathrm{a}^{-1}$ for the first period and of $-0.28 \pm 0.97 \mathrm{~m}$ w.e. $\mathrm{a}^{-1}$ for the second period was detected. For the entire Ala-Archa catchment, a glacier area change of $-5.1 \%$ from 1943 to 1977 and of $-10.6 \%$ between 1977 and 2003 was observed (Aizen et al., 2006, 2007). The mass balance sensitivity to temperature change was determined by Rasmussen (2013) as $-0.17 \mathrm{mw}$ w.e. ${ }^{\circ} \mathrm{C}^{-1}$, which is substantially lower than for the Abramov glacier.

In summer 2010, mass balance and length change measurements were re-initiated. In Fig. 8 the former and the new measurement networks are presented. Complete infor-
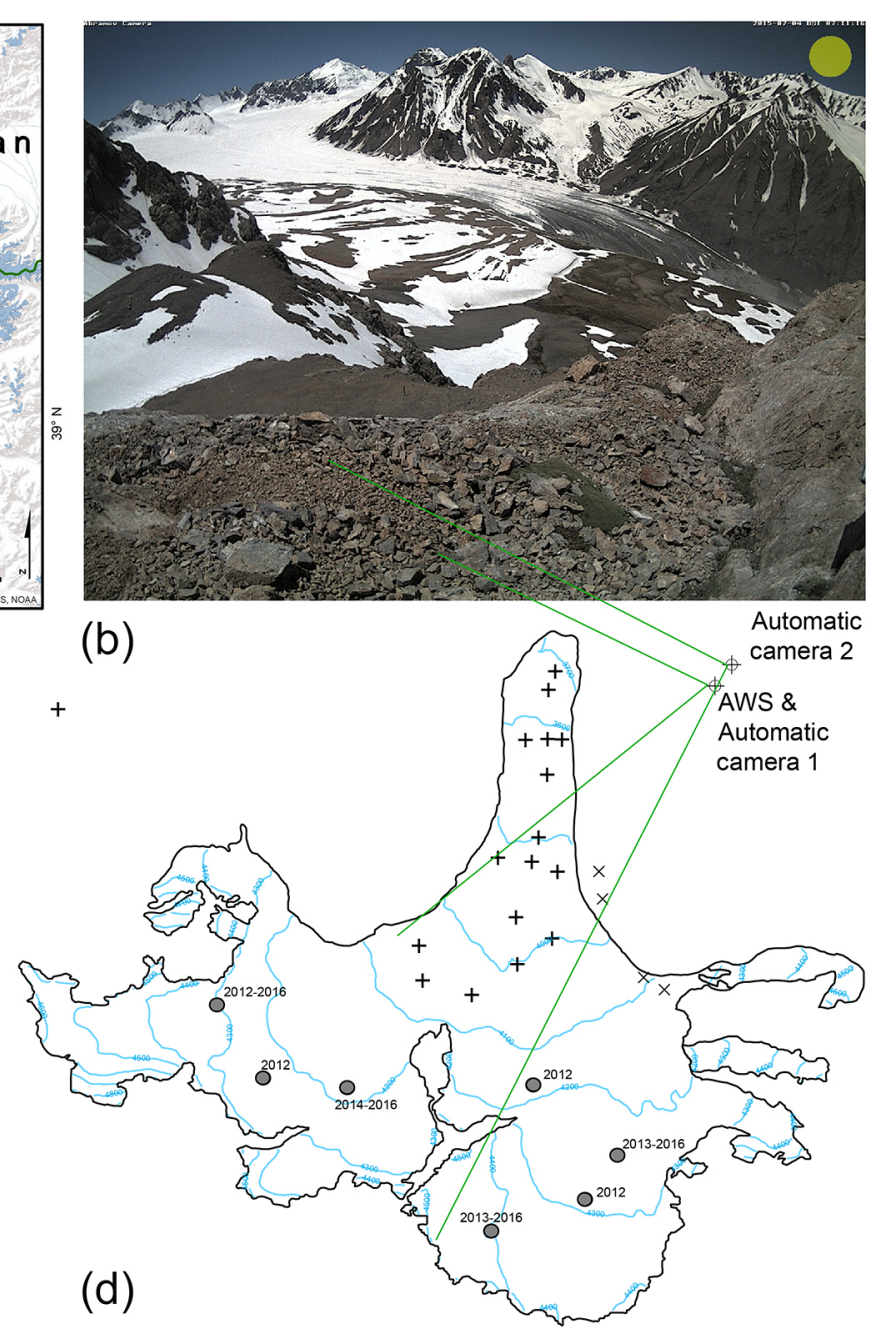

(b)

(d)

mation is available for 6 years now. During this time, the length change measurements were performed by GPS and by analysis of satellite images. The recent observations of the glacier tongue could be connected to earlier measurements by Aizen et al. $(2006,2007)$ (Fig. 7). The glaciological measurements were analysed by using a distributed mass balance model (Huss et al., 2009) (Table 3, Fig. 6). The meteorological station, installed in 2013, is situated at an altitude of $3300 \mathrm{~m}$ a.s.l. at a distance of $500 \mathrm{~m}$ away from the Golubin glacier (Schöne et al., 2013). Two further climate stations, Alplager and Baitik, are located in the Ala-Archa catchment at the altitudes of 2340 and 1580 ma.s.l., respectively. The re-initiated mass balance measurements since 2010 indicate mostly negative mass changes. In the hydrological years 2010/2011 (from 1 October 2010 until 30 September 2011) and 2015/2016, a positive mass balance was measured (Table 3). The observed cumulative glacier frontal retreat since 1861 sums up to around $1.3 \mathrm{~km}$ (see Table 5 and Fig. 7). 


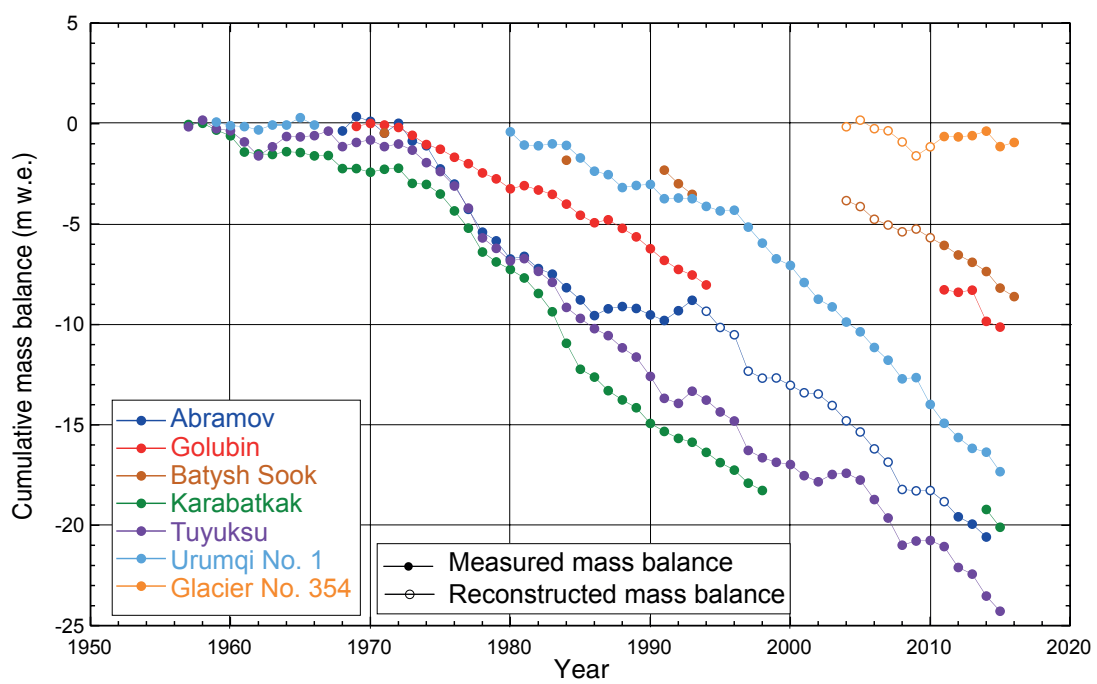

Figure 6. Cumulative mass balance measurements for glaciers in Central Asia. Filled dots are direct glaciological measurements, and nonfilled dots are reconstructed values.

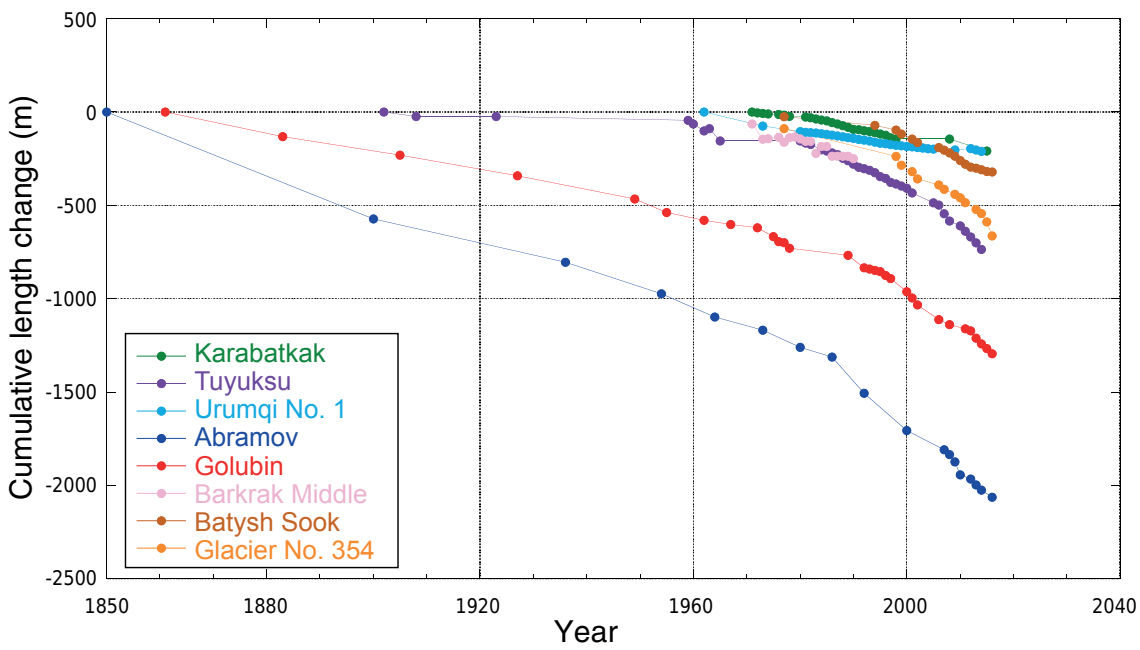

Figure 7. Cumulative front variation measurements for glaciers in Central Asia.

\subsection{Batysh Sook glacier, Kyrgyzstan}

The Batysh Sook glacier (also named Suyok (Suek) Zapadniy or Glacier No. 419 in earlier studies; WGMS, 1993; Hagg et al., 2013; Kenzhebaev et al., 2017) is located in the Sook range in the central Tien Shan in Kyrgyzstan. The range is comprised of 44 glaciers with a total area of $30.9 \mathrm{~km}^{2}$ and volume of $1.2 \mathrm{~km}^{3}$ in 2007 (Hagg et al., 2013). The Batysh Sook glacier (Fig. 1) belongs to the Naryn catchment, which is a major tributary of the Syr Darya river. The small glacier covered an area of around $1.2 \mathrm{~km}^{2}$ in 2005 and covers an altitudinal range of 3950 to 4450 ma.s.l., with an estimated volume of around $0.033 \mathrm{~km}^{3} \pm 6.5 \%$ in 2010 (Hagg et al., 2013). The glacier is assumed to be composed of a temperate accumulation zone and a cold ablation area.
According to the Tien Shan meteorological station situated at a distance of around $32 \mathrm{~km}$, the mean annual temperature is $-6.0^{\circ} \mathrm{C}$. July is the month with the highest temperatures $\left(4.4^{\circ} \mathrm{C}\right)$, and January has a mean temperature of $-21.7^{\circ} \mathrm{C}$ (1997 to 2014) (Kutuzov and Shahgedanova, 2009). Mean annual precipitation is $360 \mathrm{~mm}$ (1997 to 2014), of which up to $75 \%$ was recorded during the summer months (May to September).

Batysh Sook was already monitored during short periods in 1970/1971, 1983/1984 and from 1988 to 1991 (see Table 2, WGMS, 1993). Hagg et al. (2013) calculated an area loss of around $19.8 \%$ and a corresponding volume loss of $12.1 \%$ for all glaciers within the Sook range for the time period 1956 to 2007 . 
Table 5. Length change $\Delta L$ measurements for Abramov, Golubin, Batysh Sook and Glacier No. 354 based on GPS surveys, satellite images and maps.

\begin{tabular}{|c|c|c|c|c|c|c|c|}
\hline \multicolumn{2}{|c|}{ Abramov } & \multicolumn{2}{|c|}{ Golubin } & \multicolumn{2}{|c|}{ Batysh Sook } & \multicolumn{2}{|c|}{ Glacier No. 354} \\
\hline Period & $\Delta L(\mathrm{~m})$ & Period & $\Delta L(\mathrm{~m})$ & Period & $\Delta L(\mathrm{~m})$ & Period & $\Delta L(\mathrm{~m})$ \\
\hline 1850-1900 & -572 & $1861-1883$ & -131 & 1975-1977 & -25 & 1972-1977 & -89 \\
\hline 1900-1936 & -232 & 1883-1905 & -100 & 1977-1994 & -47 & 1977-1998 & -148 \\
\hline 1936-1954 & -169 & 1905-1927 & -110 & 1994-1998 & -24 & 1998-1999 & -47 \\
\hline 1954-1964 & -125 & 1927-1949 & -125 & 1998-1999 & -22 & 1999-2001 & -35 \\
\hline 1964-1973 & -70 & 1949-1955 & -72 & 1999-2001 & -27 & 2001-2002 & -39 \\
\hline 1973-1980 & -92 & $1955-1962$ & -42 & 2001-2002 & -18 & 2002-2006 & -33 \\
\hline 1980-1986 & -52 & $1962-1967$ & -22 & 2002-2006 & -27 & 2006-2007 & -23 \\
\hline 1986-1992 & -193 & $1967-1972$ & -17 & 2006-2007 & -15 & 2007-2009 & -27 \\
\hline 1992-2000 & -201 & $1972-1975$ & -47 & 2007-2008 & -14 & 2009-2010 & -18 \\
\hline 2000-2007 & -102 & $1975-1976$ & -26 & 2008-2009 & -18 & 2010-2011 & -25 \\
\hline 2007-2008 & -27 & 1976-1977 & -6 & 2009-2010 & -23 & 2011-2013 & -36 \\
\hline 2008-2009 & -39 & 1977-1978 & -30 & 2010-2011 & -20 & 2013-2014 & -22 \\
\hline 2009-2010 & -69 & 1978-1989 & -39 & 2011-2012 & -15 & 2014-2015 & -45 \\
\hline 2010-2012 & -22 & 1989-1992 & -65 & 2012-2013 & -6 & 2015-2016 & -76 \\
\hline 2012-2013 & -32 & 1992-1993 & -7 & 2013-2014 & -9 & & \\
\hline 2013-2014 & -27 & 1993-1994 & -8 & 2014-2015 & -9 & & \\
\hline 2014-2016 & -38 & 1994-1995 & -7 & 2015-2016 & -3 & & \\
\hline & & 1995-1996 & -20 & & & & \\
\hline & & 1996-1997 & -16 & & & & \\
\hline & & 1997-2000 & -71 & & & & \\
\hline & & 2000-2001 & -34 & & & & \\
\hline & & 2001-2002 & -37 & & & & \\
\hline & & 2002-2006 & -79 & & & & \\
\hline & & 2006-2008 & -27 & & & & \\
\hline & & 2008-2011 & -22 & & & & \\
\hline & & 2011-2012 & -12 & & & & \\
\hline & & 2012-2013 & -38 & & & & \\
\hline & & 2013-2014 & -32 & & & & \\
\hline & & 2014-2015 & -25 & & & & \\
\hline & & 2015-2016 & -27 & & & & \\
\hline
\end{tabular}

Since 2010, several stakes and some snow pits have been measured on an annual basis on the Batysh Sook glacier. In Fig. 9 the old and the new measurement networks are presented. The mass balance is analysed using a distributed mass balance model (Huss et al., 2009). The results indicate a continuous negative mass balance of about -0.4 to -0.8 mw.e. $\mathrm{a}^{-1}$ since $2011 / 2012$ (Table 3 ). The observed cumulative glacier frontal retreat since 1975 sums up to around $0.32 \mathrm{~km}$ (see Table 5 and Fig. 7).

A reconstruction of past mass balances for the period 2004 to 2010 was performed by Kenzhebaev et al. (2017) using a calibrated distributed temperature index mass balance model. For the reconstructed period an average annual mass balance of $-0.39 \pm 0.26 \mathrm{mw}$.e. $\mathrm{a}^{-1}$ was found. For the direct measured period 2011 to 2016, three different methods were applied. The first method, the profile method, revealed a mass loss of $-0.41 \pm 0.28$ mw.e. $\mathrm{a}^{-1}$; the second method, the contour line, resulted in a negative mean mass balance of $-0.34 \pm 0.20 \mathrm{mw}$.e. $\mathrm{a}^{-1}$; and the third method, based on model extrapolation, calculated a value of $-0.43 \pm 0.16$ mw.e. $\mathrm{a}^{-1}$

\subsection{Glacier No. 354, Kyrgyzstan}

Glacier No. 354 is situated in the southern part of the Akshiirak glacierised massif, inner Tien Shan in Kyrgyzstan (Fig. 1). According to Aizen et al. (2006), the range contains 178 glaciers ( $87 \%$ of them are valley-type glaciers) covering an area of $371 \mathrm{~km}^{2}$. The Akshiirak glaciers on the eastern and southern part of the mountain range drain into the Saridjaz river, a tributary of the Tarim River via the Aksu River, and the runoff of the glaciers on the western part contributes to the flow of the Naryn River. The glacier had a surface area of $6.41 \mathrm{~km}^{2}$ in 2014 (Kronenberg et al., 2016). The accumulation area is composed of three basins, and the glacier tongue is directed to the northwest. The glacier covers an altitudinal range of around 3750 to $4650 \mathrm{~m}$ a.s.l. Hagg et al. (2013) performed GPR measurements on the glacier tongue and used 

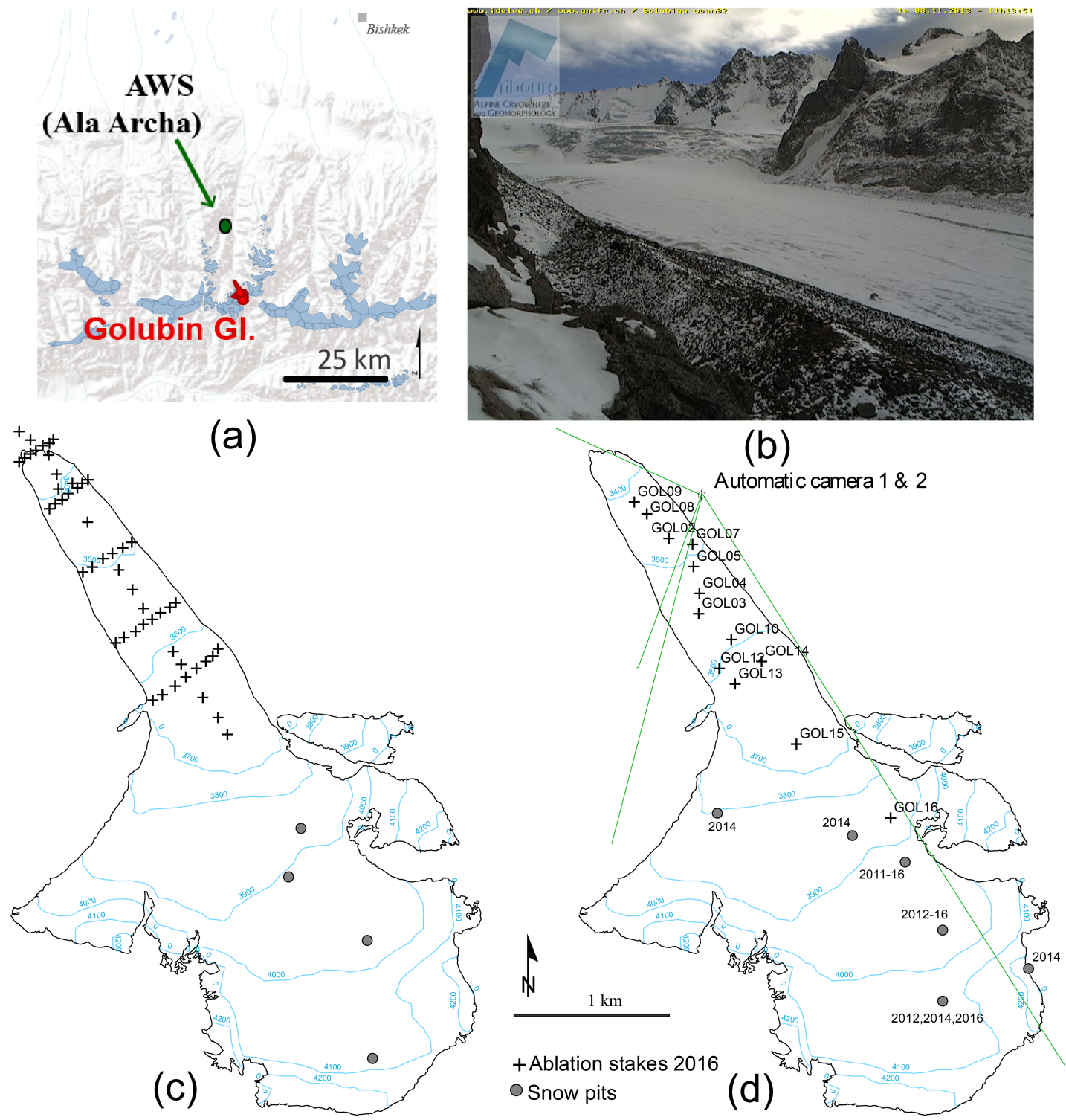

Figure 8. Historical (c) and new (d) mass balance network on the Golubin glacier (Kyrgyzstan) with corresponding (overview) map (a) and snow line camera picture (b).

a simplified ice mechanical approach to determine the total volume of this glacier to be $0.272 \pm 0.022 \mathrm{~km}^{3}$. Pieczonka and Bolch (2015) quantified the geodetic mass balance for Glacier No. 354 (Bordu-Yushny in their study) from 1975 to 1999 as $-0.79 \pm 0.25$ m w.e. $\mathrm{a}^{-1}$.

The Akshiirak range is closely situated to the Sook range, and the closest meteorological station is again the Tien Shan station ( $14 \mathrm{~km}$ distance). The climate is similar to the one of the Batysh Sook glacier.

Glacier No. 354 was selected to replace the previously monitored the Sary-Tor glacier due to current access restrictions because of mining activities. Sary-Tor has mass balance observations based on the glaciological method for the period of 1985 to 1989 (Dyurgerov et al., 1994), and its mass balance was reconstructed for the period 1930 to 1988 by Ushnurtsev (1991). Mass balance measurements were reinitiated in 2013 by a team of Russian and Kyrgyz scientists. The front variations of Sary-Tor indicate a retreat of $70 \mathrm{~m}$ from 1932 to 1943, no changes from 1943 to the mid-1970s, and a retreat of $220 \mathrm{~m}$ from 1977 to 1995 and of $90 \mathrm{~m}$ from 1995 to 2003 (Aizen et al., 2007).

Kronenberg et al. (2016) presented a reconstruction of the seasonal mass balance of Glacier No. 354 from 2003 to 2010. This reconstruction is based on an analysis of the annual measurements of stakes and snow pits of the years 2010 to 2014 (Fig. 10). The glaciological data were used to calibrate 


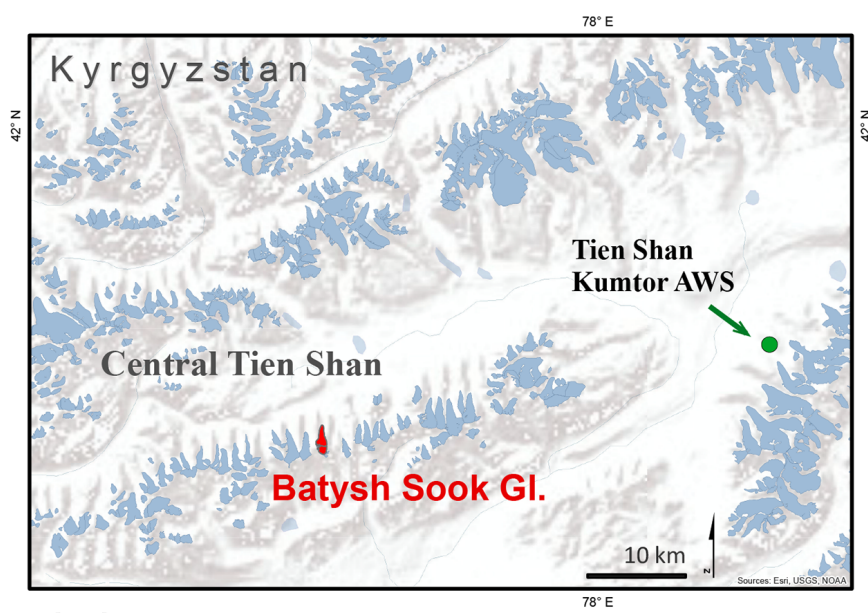

(a)

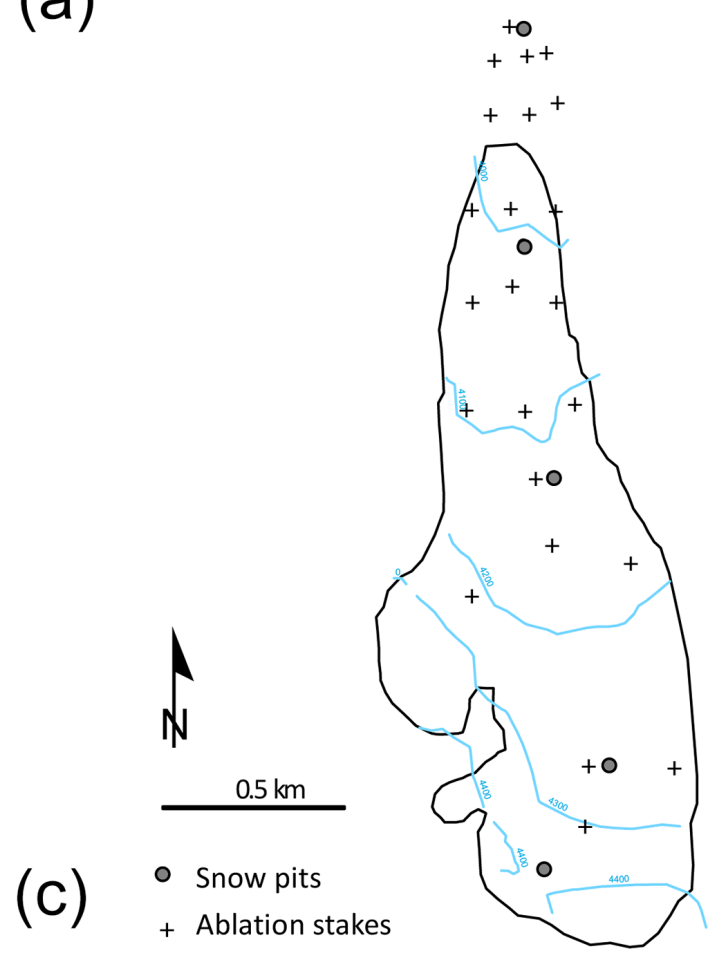

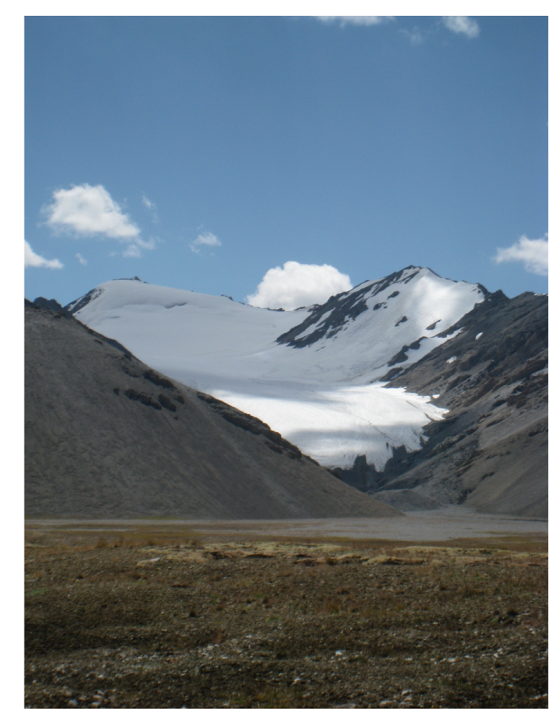

(b)

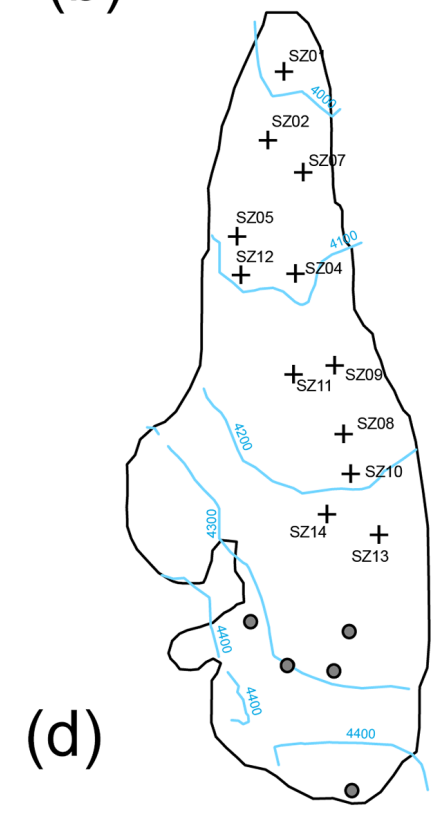

Figure 9. Historical (c) and new (d) mass balance network on the Batysh Sook glacier (Kyrgyzstan) with corresponding (overview) map (a) and picture (b).

a distributed mass balance model, which was then used to reconstruct the seasonal mass balances since 2003. In addition, winter accumulation measurements were performed in spring 2014 and also used for model calibration. Furthermore, the geodetic volume change was determined based on two high-resolution satellite stereo images acquired in 2003 and 2012 and used to validate the modelled cumulative glacier-wide mass balance. For the period 2003 to 2012, an annual mass balance of $-0.40 \pm 0.10 \mathrm{mw}$.e. $\mathrm{a}^{-1}$ was modelled. This result corresponds well with the geodetic mass balance of $-0.48 \pm 0.07 \mathrm{~m}$ w.e. $\mathrm{a}^{-1}$ for the same period (see
Tables 3 and 4, Kronenberg et al., 2016). The observed cumulative glacier frontal retreat since 1972 sums up to around $0.66 \mathrm{~km}$ (see Table 5 and Fig. 7).

\subsection{Barkrak Middle, Uzbekistan}

The Barkrak Middle glacier is located in the Oygaing valley in the Pskem catchment in the western Tien Shan, Uzbekistan (Fig. 1). The Pskem River drains into Chirchik River, a tributary of the Syr Darya river. The area of the glaciers in the Pskem River basin including the Oygaing and the up- 

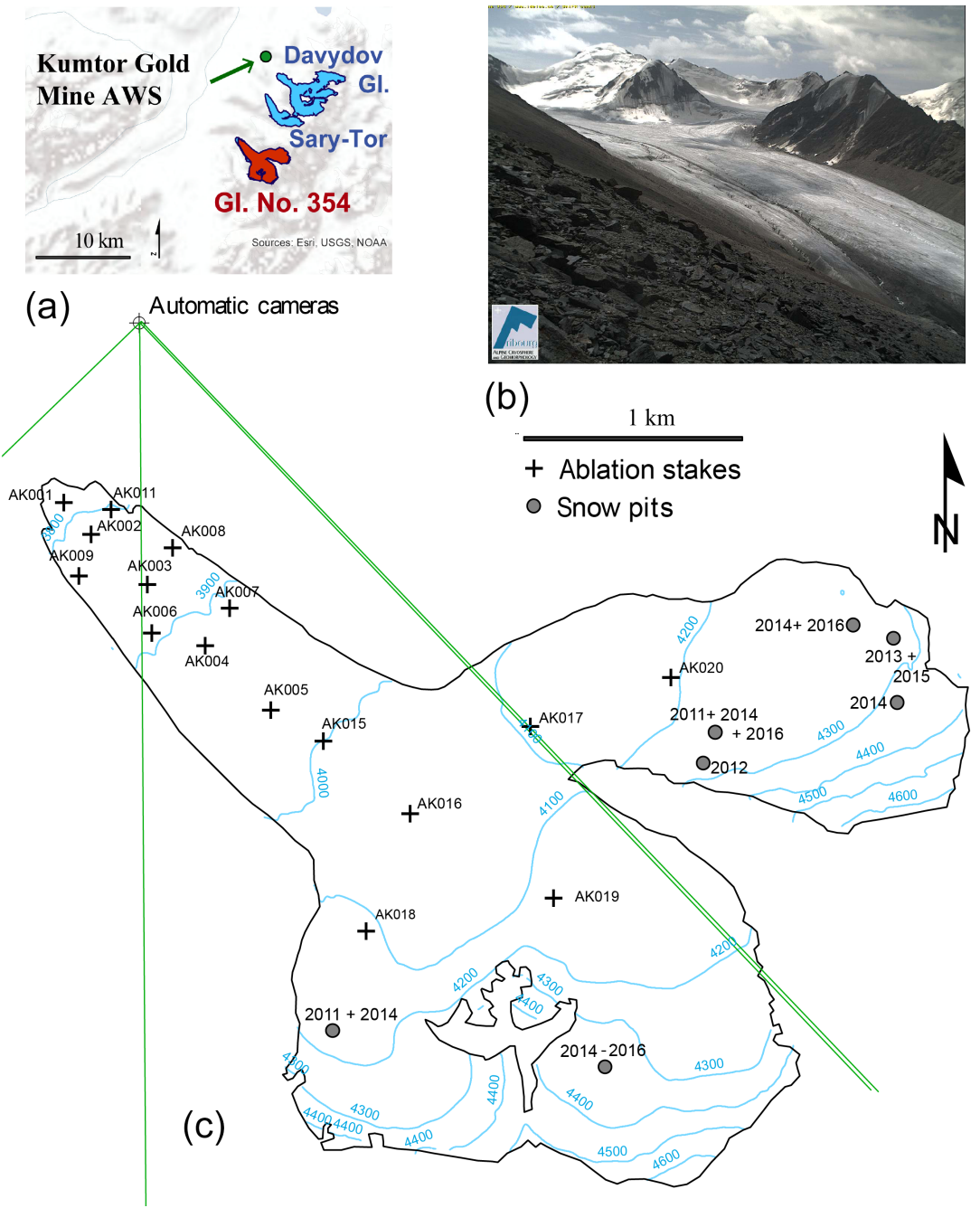

Figure 10. Mass balance network (c) on Glacier No. 354 (Kyrgyzstan) with corresponding (overview) map (a) and snow line camera (b).

per Maydan valley (located in Kazakhstan) was $93.6 \mathrm{~km}^{2}$ in the year 2007 (Semakova et al., 2016). The area of Barkrak Middle is $2.18 \mathrm{~km}^{2}$ (Semakova et al., 2016) and the volume is $0.087 \mathrm{~km}^{3}$ (Huss and Farinotti, 2012).

Between 1960 and 2010, the glacierised area decreased by $23 \%$ in the Pskem River catchment, and, more specifically, a $16.8 \%$ decrease in glacier area was observed from 1980 to 2001 in the basin of the Oygaing river, where the Barkrak Middle glacier is located (Semakova et al., 2016). For the Barkrak Middle glacier, observation data of length change exist from 1971 to 1990 , with a total cumulative retreat of 249 m (see Fig. 7).

In 2016, a new mass balance network with a total of 11 stakes was established (Fig. 11). In addition, a meteorological station in the glacier forefield and an automatic snow line camera were installed (Fig. 11).

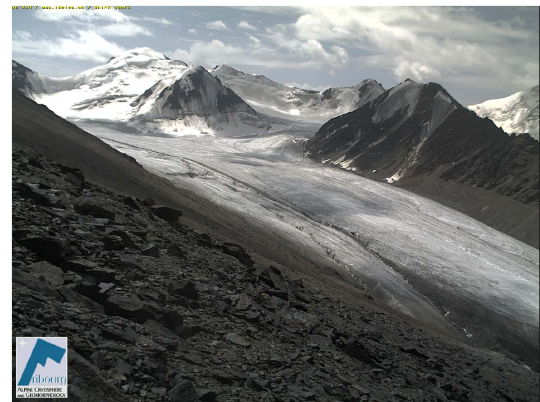

(b)

N 


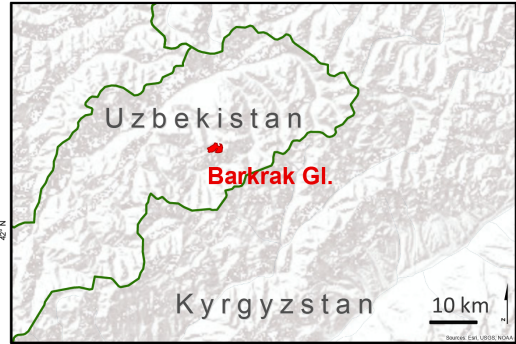

(a)

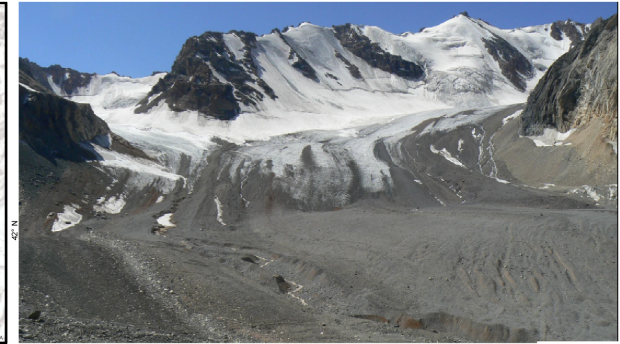

(b)
AWS

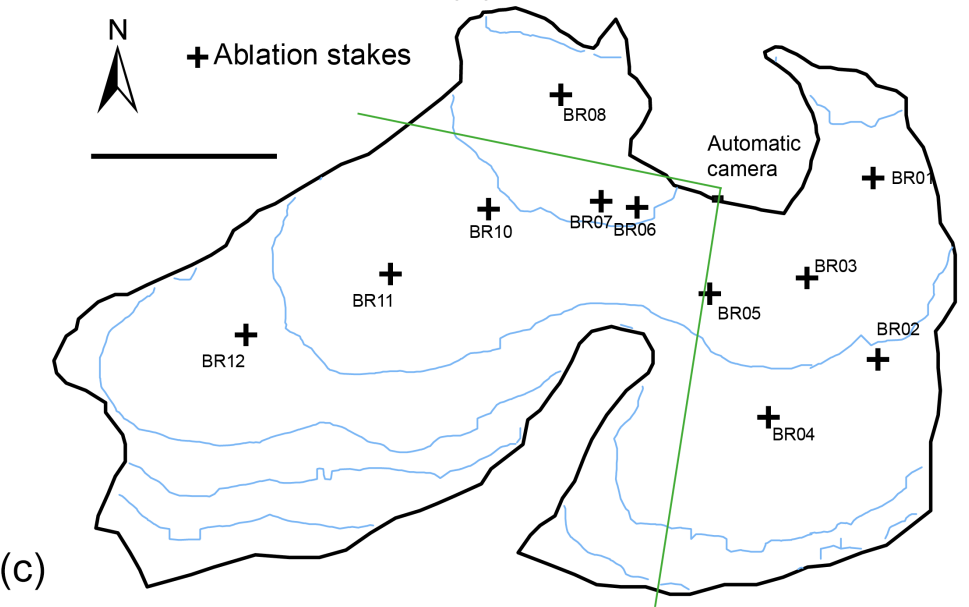

Figure 11. Mass balance network (c) on Barkrak Middle (Uzbekistan) with corresponding (overview) map (a) and picture (b).

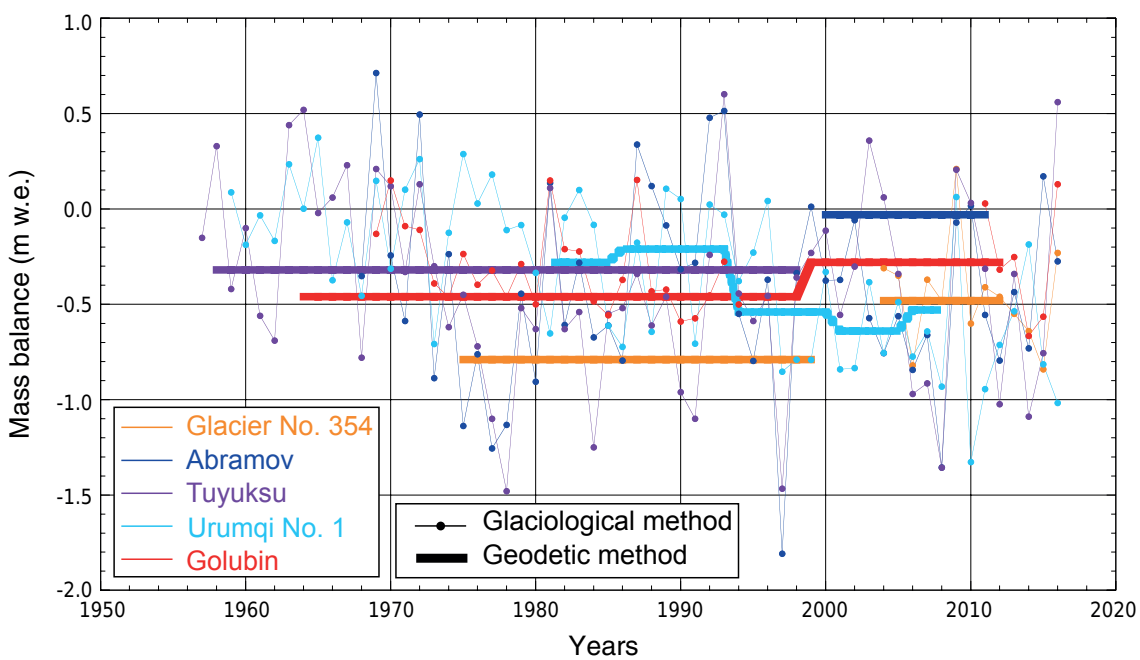

Figure 12. Comparison of glaciological and geodetic mass balance for glaciers in Central Asia. The geodetic mass balances are from Hagg et al. (2004) (Tuyuksu), Wang et al. (2014) (Urumqi Glacier No. 1), Pieczonka and Bolch (2015) and Kronenberg et al. (2016) (Glacier No. 354), and Gardelle et al. (2013) (Abramov). The glaciological data are provided by WGMS (2013).

studies underlining the findings (Aizen et al., 1995b; Bolch et al., 2011, 2012; Pieczonka et al., 2013; Gardelle et al., 2013; Pieczonka and Bolch, 2015; Bolch, 2015; Kronenberg et al., 2016).

The network of glaciological and geodetic measurements in the Tien Shan mountains has been strongly improved by the re-establishment of the monitoring programmes starting in 2010. In the Pamir Mountains, however, glacier mass balance measurements are still sparse as only the Abramov glacier in the most northwestern part is monitored. This glacier is not representative of the entire Pamir, which also contains glaciers at much higher altitudes that respond differ- 
ently to atmospheric warming (e.g. Kääb et al., 2015, 2012; Gardner et al., 2013; Gardelle et al., 2013).

Length changes are an important element of glacier monitoring. Direct measurements extend back into the 19th century in several mountain ranges, and some reconstructions based on geomorphological dating extend back to the 16th century (Zemp et al., 2015). In general, the cumulative front variation measurements for the investigated glaciers in Central Asia reveal a long-term glacier retreat (see Table 3, Fig. 7). Here we used a simple parameterisation scheme developed by Haeberli and Hoelzle (1995) and used by Hoelzle et al. (2003) to convert curves of cumulative glacier advance and retreat into time series of temporally averaged mass balance by applying a continuity model developed by Nye (1960) to infer mean mass balance changes over longer time periods. This approach considers step changes after a full dynamic response and new equilibrium of the glacier based on the assumption that a mass balance change leads to a corresponding glacier length change depending only on the original length of the glacier and its annual mass balance (ablation) at the glacier terminus. Calculating these values for Abramov (for the period 18502016) results in $-0.35 \mathrm{~m}$ w.e. $\mathrm{a}^{-1}$, for Golubin (1861-2016) around $-0.2 \mathrm{mw}$.e. $\mathrm{a}^{-1}$, and for Batysh Sook (1975-2016) and Glacier No. 354 (1972-2016) around -0.35 m w.e. $\mathrm{a}^{-1}$.

\section{Discussion}

We demonstrate that a valuable glaciological dataset is available for the Central Asian mountains, particularly for the Tien Shan, despite different historical backgrounds and changing methodological aspects. New monitoring networks in combination with historical measurements will generate highly valuable baseline data for future research, climate change observations, assessment of climate change impacts and related adaptation measures, including water resource management. Continuous long-term support and cooperation among several countries and institutions is required to keep the successfully re-established measurements alive. The newly developed strategy and its implementation to connect in situ measurements with remote sensing and numerical modelling techniques (see Fig. 2) will allow the establishment of an efficient glacier monitoring programme. This will guarantee an optimum between available human capacity and efforts, sustainable financial coverage and data quality, offering a feasible way to perform long-term monitoring. Our approach, implemented in Kyrgyzstan and Uzbekistan, has to be proven during the next years and should be further developed. Over the last years, it delivered promising results, although there are still many improvements possible. One of the most urgent needs is capacity building, i.e. the education of young local scientists being able to continue the monitoring programme independently (Nussbaumer et al., 2017).
Our approach also reveals that, on a scientific basis, an in-depth re-evaluation of long-term geodetic mass changes on all selected glaciers is absolutely necessary. Most geodetic measurements (e.g. for Glacier No. 354, Urumqi Glacier No. 1 and Tuyuksu) match well with the glaciological mass balances (Fig. 12). All these measurements show almost persistently negative mass balances since the mid-20th century. At the Abramov glacier, however, considerable differences between geodetic and reconstructed glaciological measurements were found (Fig. 12 and Table 4). For the period 2000 to 2011, Barandun et al. (2015) determined a negative value of $-0.51 \pm 0.17$ mw.e. $\mathrm{a}^{-1}$, whereas Gardelle et al. (2013) reported a mass balance of $-0.03 \pm 0.14 \mathrm{mw}^{\mathrm{s}} \mathrm{a}^{-1}$ for the same period. The geodetic measurements are subject to considerable uncertainties that are, for example, related to the underestimated penetration of the radar signals into snow and firn in the accumulation areas during the acquisition of the SRTM mission in the year 2000 (Paul et al., 2013). This has been confirmed by other studies using ICESat measurements in the same region (Kääb et al., 2015, 2012; Gardner et al., 2013) and by ground-penetrating radar measurement in the accumulation area of the Abramov glacier (Barandun et al., 2015). This shows the need for further analysis of existing aerial and satellite data in order to create additional high-accuracy elevation models. Another problem encountered during the homogenisation process of the mass balance time series was a considerable inconsistency, which is mainly related to different interpretations of the former stake networks or to missing measurements.

Glacier frontal variations complement the mass balance measurements. They show a continuous retreating trend for the last decades and century. The inferred estimates of mass change calculated based on the length change measurements are in quite good accordance with the mass balance measurements.

\section{Conclusions}

This paper demonstrates the richness of the historical dataset from the long-term glacier measurements available in Central Asia and particularly in Kyrgyzstan, and it introduces the (re-)established glacier measurement network highlighting the importance of capacity building to make the efforts sustainable. In connection with the new glacier monitoring strategy and its current implementation, the long-term in situ data are fundamental to understanding the relevant processes and the impact of climate change on glaciers in the Tien Shan and the Pamir-Alay and the impacts for the people living nearby as well as in far distances downstream. Therefore, the cryospheric ECV "glacier" is an important variable, for which sustainable long-term monitoring has to be ensured not only in industrial countries but also in developing countries. Without the long-term measurements, questions such as the future behaviour of glaciers, their possible disappearance 
and the impacts for society cannot be answered comprehensively. Only well-validated and well-calibrated models based on sound process understanding and high-quality data will ensure projections with an acceptable level of uncertainty. These models and their outputs are the only tools for estimating future runoff evolution in one of the driest continental regions of the Northern Hemisphere, where future water shortage due to decreased glacierisation has the potential to lead to pronounced political instability and drastic ecological changes, and it might even endanger future food security in a highly populated region. This highlights the importance of in situ monitoring networks of all ECVs within national and international climate services and their use together with remote sensing and numerical models.

Data availability. The dataset presented here is part of WGMS (2017).

Competing interests. The authors declare that they have no conflict of interest.

Acknowledgements. We thank Florian Denzinger, Murataly Duishonakunov, Mauro Fischer, Alyssa Ghirlanda, Saskia Gindraux, Andreas Kääb, David Kriegel, Mario Kummert, Nico Mölg, Kathrin Naegeli, Anton Neureiter, Dmitry Petrakov, Stephan Reisenhofer, Helene Rieck, Julia Schmale, Alina Sharshebaev, Leo Sold, Philipp Schuppli, Alexander Zubovich, Almaz Andashev, Tiynstiyk Aktanov and Mukhammed Esenamanov for their valuable support in the field. Tobias Bolch is acknowledged for sharing data. The project was only possible thanks to the support of the Federal Office of Meteorology and Climatology MeteoSwiss through the project CATCOS (Capacity Building and Twinning for Climate Observing Systems), contract no. 7F-08114.1 between the Swiss Agency for Development and Cooperation and MeteoSwiss and the project CICADA (Cryospheric Climate Services for improved Adaptation), and contract no. 81049674 between Swiss Agency for Development and Cooperation and the University of Fribourg. The CAWa (Central Asian Water) project (http://www.cawa-project.net) was supported by the German Federal Foreign Office (contract no. AA7090002) as a part of the "Berlin Process". This study was also supported by the Swiss National Science Foundation (SNSF) by the following two projects: "Snowline observations to remotely derive seasonal to sub-seasonal glacier mass balance in the Tien Shan and Pamir Mountains", grant 155903, and "Changing glacier firn in Central Asia and its impact on glacier mass balance", grant 169453. Further support came from the European Research Council (FP/2007-2013, ERC grant agreement no. 320816). We are also grateful to all collaborators of the Central Asian Institute for Applied Geosciences for their continued support of this long-term project.

Edited by: Luis Vazquez

Reviewed by: two anonymous referees

\section{References}

Ahlmann, H.: Le niveau de glaciation comme fonction de l'accumulation d'humidité sous form solide, Geogr. Ann. A, 6, 223-272, 1924.

Aizen, V.: Reconstrktiya balansa massy lednika Golubina, Materialy Glyatsiologicheskikh Issledovaniy, 62, 119-126, 1988.

Aizen, V., Aizen, E., and Melack, J.: Present and future impact of snow cover and glaciers on runoff from mountain regions - comparison between Alps and Tien Shan, in: Biochemistry of Sesonally Snow-Covered Catchments, vol. 228, 413-430, IAHS, Boulder, Colorado, USA, 1995a.

Aizen, V., Aizen, E., and Melack, J.: Climate, snow cover, glaciers, and runoff in the Tien Shan, Central Asia, Water Resour., 31, 1113-1129, 1995 b.

Aizen, V., Surazakov, A., Kuzmichenok, V., and Aizen, E.: Glacier changes in central and northern Tien Shan during the last 140 years based on surface and remote sensing data, Ann. Glaciol., 43, 202-213, 2006.

Aizen, V., Aizen, E., and Kuzmichenok, V.: Geo-informational simulation of possible changes in Central Asian water resources, Global Planet. Change, 56, 341-358, 2007.

Arendt, A., Bliss, A., Bolch, T., Cogley, J., Gardner, A., Hagen, J., Hock, R., Huss, M., Kaser, G., Kienholz, C., Pfeffer, W., Moholdt, G., Paul, F., Radic, V., Andreassen, L., Bajracharya, S., Barrand, N., Beedle, M., Berthier, E., Bhambri, R., Brown, I., Burgess, E., Burgess, D., Cawkwell, F., Chinn, T., Copland, L., Davies, B., De Angelis, H., Dolgova, E., Earl, L., Filbert, K., Forester, R., Fountain, A., Frey, H., Giffen, B., Glasser, N., Guo, W., Gurney, S., Hagg, W., Hall, D., Haritashya, U., Hartmann, G., Helm, C., Herreid, S., Howat, I., Kapustin, G., Khromova, T., König, M., Kohler, J., Kriegel, D., Kutuzov, S., Lavrentiev, I., Le Bris, R., Liu, S., Lund, J., Manley, W., Mayer, C., Miles, E., Li, X., Menounos, B., Mercer, A., Mölg, N., Mool, P., Nosenko, G., Negrete, C., Nuth, C., Petterson, R., Racoviteanu, A., Ranzi, R., Rastner, P., Rau, F., Raup, B., Rich, J., Rott, H., Schneider, C., Seliverstov, Y., Sharp, M., Sigurdsson, O., Stokes, C., Wheate, R., and Winsvold, S. W.: Randolph Glacier Inventory: A Dataset of Global Glacier Outlines: Version 5.0, Digital media, Global Land Ice Measurements from Space, Boulder, Colorado, USA, 2015.

Barandun, M., Huss, M., Sold, L., Farinotti, D., Azisov, E., Salzmann, N., Usulbaliev, R., Merkushkin, A., and Hoelzle, M.: Reanalysis of seasonal mass balance at Abramov glacier 19682014, J. Glaciol., 61, 1103-1117, 2015.

Bauder, A., Funk, M., and Huss, M.: Ice-volume changes of selected glaciers in the Swiss Alps since the end of the 19th century, Ann. Glaciol., 46, 145-149, 2007.

Benn, D. I. and Lehmkuhl, F.: Mass balance and equilibrium-line altitudes of glaciers in high-mountain environments, Quatern. Int., 65-6, 15-29, 2000.

Berthier, E., Arnaud, Y., Vincent, C., and Rémy, F.: Biases of SRTM in high-mountain areas: Implications for the monitoring of glacier volume changes, Geophys. Res. Lett., 33, L08502, https://doi.org/10.1029/2006GL025862, 2006.

Berthier, E., Schiefer, E., Clarke, G., Menounos, B., and Rémy, F.: Contribution of Alaskan glaciers to sea-level rise derived from satellite imagery, Nat. Geosci., 3, 92-95, 2010. 
Bolch, T.: Glacier area and mass changes since 1964 in the Ala Archa Valley, Kyrgyz Ala-Too, northern Tien Shan, Ice Snow, 129, 28-39, 2015.

Bolch, T. and Buchroithner, M.: Suitability of medium scale topographic maps and the SRTM DEM to estimate glacier volume changes in the Northern Tien Shan, Tech. rep., Institute of Geography, Russian Academy of Sciences, Moscow, Russia, https://doi.org/10.15356/IS.2015.01.03, 2008.

Bolch, T., Pieczonka, T., and Benn, D. I.: Multi-decadal mass loss of glaciers in the Everest area (Nepal Himalaya) derived from stereo imagery, The Cryosphere, 5, 349-358, https://doi.org/10.5194/tc-5-349-2011, 2011.

Bolch, T., Kulkarni, A., Kääb, A., Huggel, C., Paul, F., Cogley, J., Frey, H., Kargel, J., Fujita, K., Scheel, M., Bajracharya, S., and Stoffel, M.: The state and fate of Himalyan glaciers, Science, 336, 310-314, 2012.

Braithwaite, R.: Can the mass balance of a glacier be estimated from its equilibrium line altitude?, J. Glaciol., 30, 364-368, 1984.

Braithwaite, R. and Müller, F.: On the Parameterization of Glacier Equilibrium Line Altitude, vol. 126 of IAHS-AISH, International Association of Hydrological Sciences, Proceedings of the Riederalp Workshop, September 1978, Riederalp, Valais, Switzerland, 1980.

Chen, Y., Li, W., Deng, H., Fang, G., and Li, Z.: Changes in Central Asia's water tower: past, present and future, Sci. Rep.-UK, 6, 35458, https://doi.org/10.1038/srep35458, 2016.

Chinn, T., Salinger, J., Fitzharris, B., and Willsman, A.: Annual ice volume changes 1976-2008 for the New Zealand Southern Alps, Global Planet. Change, 92-93, 105-118, 2012.

Cogley, J., Hock, R., Rasmussen, A., Bauder, A., Braithwaite, R., Jansson, P., Kaser, G., Möller, M., Nicholson, L., and Zemp, M.: Glossary of Glacier Mass Balance and Related Terms, vol. 86 of IHP-VII Technical Documents in Hydrology, IACS Contribution No. 2, Paris, France, 2011.

Duethmann, D., Bolch, T., Farinotti, D., Kriegel, D., Vorogushyn, S., Merz, B., Pieczonka, T., Jiang, T., Su, B., and Güntner, A.: ttribution of streamflow trends in snow and glacier meltdominated catchments of the Tarim River, Central Asia, Water Resour. Res., 351, 4727-4750, 2015.

Dyurgerov, M.: Glacier mass balance and regime: data of measurements and analysis, Occasional Paper, No. 55, Institute of Arctic and Alpine Research, University of Colorado, Boulder, Colorado, USA, 88 pp., 2002.

Dyurgerov, M., Mikhalenko, V., Kunakhovitch, M., Ushnurtsev, S., Liu, C., and Xie, Z.: On the cause of glacier mass balance variations in the Tien Shan mountains, GeoJournal, 33, 311-317, 1994.

Farinotti, D., Longuevergne, L., Moholt, G., Duethmann, D., Mölg, T., Bolch, T., Vorogushyn, S., and Güntner, A.: Substantial glacier mass loss in the Tien Shan over the past 50 years, Nat. Geosci., 8, 716-722, https://doi.org/10.1038/NGEO2513, 2015.

Gardelle, J., Berthier, E., and Arnaud, Y.: Slight mass gain of Karakoram glaciers in the early twenty-first century, Nat. Geosci., 5, 322-325, https://doi.org/10.1038/NGEO1450, 2012.

Gardelle, J., Berthier, E., Arnaud, Y., and Kääb, A.: Regionwide glacier mass balances over the Pamir-KarakoramHimalaya during 1999-2011, The Cryosphere, 7, 1263-1286, https://doi.org/10.5194/tc-7-1263-2013, 2013.
Gardner, A. S. and Moholdt, G., Cogley, J., Wouters, B., Arendt, A., Wahr, J., Berthier, E., Hock, R., Pfeffer, W., Kaser, G., Ligtenberg, S., Bolch, T., Sharp, M., Hagen, J., van den Broeke, M., and Paul, F.: A reconciled estimate of glacier contributions to sea level rise: 2003 to 2009, Science, 340, 852-857, 2013.

Glazirin, G., Kamnyansky, G., and Pertziger, F.: Regime of Abramov Glacier, Gidrometeoizat, Hydrometeo Publishing, Leningrad, Russia, 1993.

Glazirin, G., Braun, L., and Shchetinnikov, A.: Sensitivity of mountain glacierization to climatic changes in Centra Asia, Z. Gletscherkunde Glazialgeologie, 38, 71-76, 2002.

Haeberli, W. and Hoelzle, M.: Application of inventory data for estimating characteristics of and regional climate-change effects on mountain glaciers: a pilot study with the European Alps, Ann. Glaciol., 21, 206-212, 1995.

Haeberli, W., Hoelzle, M., Paul, F., and Zemp, M.: Integrated monitoring of mountain glacier as key indicators of global climate change: the European Alps, Ann. Glaciol., 46, 150-160, 2007.

Hagg, W., Braun, L., Uvarov, V., and Makarevich, K.: A comparison of three methods of mass-balance determination in the Tuyuksu glacier region, Tien Shan, Central Asia, J. Glaciol., 50, 505-510, 2004.

Hagg, W., Braun, L., Weber, M., and Brecht, M.: Runoff modelling in glacierized Central Asia catchments for present-day and future climate, Nord. Hydrol., 37, 1-13, 2006.

Hagg, W., Braun, L., Kuhn, M., and Nesgaard, T.: Modelling of hydrological response to climate change in glacierized Central Asian catchments, J. Hydrol., 332, 40-53, 2007.

Hagg, W., Mayer, C., Lambrecht, A., Kriegel, D., and Azizov, E.: Glacier changes in the Big Naryn basin, Central Tian Shan, Global Planet. Change, 110, 40-50, 2013.

Haritashya, U., Bishop, M., Shroder, J., Bush, A., and Bulley, H.: Space-based assessment of glacier fluctuations in the Wakhan Pamir, Afghanistan, Climatic Change, 94, 5-18, 2009.

Hoelzle, M., Haeberli, W., Dischl, M., and Peschke, W.: Secular glacier mass balances derived from cumulative glacier length changes, Global Planet. Change, 36, 295-306, 2003.

Hulth, J., Rolstad Denby, C. and Hock, R.: Estimating glacier snow accumulation from backward calculation of melt and snowline tracking, Ann. Glaciol., 54, 1-7, 2013.

Huss, M.: Density assumptions for converting geodetic glacier volume change to mass change, The Cryosphere, 7, 877-887, https://doi.org/10.5194/tc-7-877-2013, 2013.

Huss, M. and Farinotti, D.: Distributed ice thickness and volume of all glaciers around the globe, J. Geophys. Res.-Earth, 117, F04010, https://doi.org/10.1029/2012JF002523, 2012.

Huss, M., Bauder, A., Funk, M., and Hock, R.: Determination of the seasonal mass balance of four Alpine glaciers since 1865, J. Geophys. Res.-Earth, 113, F01015, https://doi.org/10.1029/2007JF000803, 2008.

Huss, M., Bauder, A., and Funk, M.: Homogenization of long-term mass-balance time series, Ann. Glaciol., 50, 198-206, 2009.

Huss, M., Sold, L., Hoelzle, M., Stokvis, M., Salzmann, N., Farinotti, D., and Zemp, M.: Toward remote monitoring of subseasonal glacier mass balance, Ann. Glaciol., 63, 85-93, 2013.

Immerzeel, W., van Beek, L., and Bierkens, M.: Climate change will affect the Asian water towers, Science, 328, 1382-1385, https://doi.org/10.1126/science.1183188, 2010. 
IPCC: Climate Change 2013: The physical science basis, Contribution of working group I to the fifth assessment report of the intergovernmental panel of climate change, p. 1535, Cambridge University Press, Cambridge, UK, 2013.

Kääb, A., Berthier, E., Nuth, C., Gardelle, J., and Arnaud, Y.: Contrasting patterns of early twenty-first-century glacier mass changes in the Himalayas, Nature, 488, 495-498, 2012.

Kääb, A., Treichler, D., Nuth, C., and Berthier, E.: Brief Communication: Contending estimates of 2003-2008 glacier mass balance over the Pamir-Karakoram-Himalaya, The Cryosphere, 9, 557564, https://doi.org/10.5194/tc-9-557-2015, 2015.

Kamnyansky, G.: Abramov glacier mass balance observations resume (1967-1998), Proc. SANIGMI, 161, 122-131, 2001.

Kaser, G., Fountain, A., and Jansson, P.: A Manual for Monitoring the Mass Balance of Mountain Glaciers, vol. 59, International Hydrological Programme, Paris, France, 2003.

Kaser, G., Grosshauser, M., and Marzeion, B.: Contribution potential of glaciers to water availability in different climate regimes, P. Natl. Acad. Sci. USA, 107, 20223-20227, 2010.

Kenzhebaev, R., Barandun, M., Kronenberg, M., Yaning, C., Usubaliev, R., and Hoelzle, M.: Mass balance observations and reconstruction for Batysh Sook Glacier, Tian Shan, from 2004 to 2015, Cold Reg. Sci. Technol., 135, 76-89, 2017.

Khromova, T., Osipova, G., Tsvetkov, D., Dyurgerov, M., and Barry, R.: Changes in glacier extent in the eastern Pamir, Central Asia, determined from historical data and ASTER imagery, Remote Sens. Environ., 102, 24-32, 2006.

Khromova, T., Nosenko, G., Kutuzov, S., A., M., and Chernova, L.: Glacier area changes in Northern Eurasia, Environ. Res. Lett., 9, 1029, https://doi.org/10.1088/1748-9326/9/1/015003, 2014.

Kislov, B., Nozdrukhin, V., and Pertziger, F.: Temperature regime of the active layer of Lednik Abramov, Materialy Glyatsiologicheskikh Issledovaniy = Data of Glaciological Studies, 30, 199204, 1977 (in Russian).

Konovalov, V. and Desinov, L. V.: Remote sensing monitoring of the long-term regime of the Pamirs glaciers. Remote Sensing for Environmental Monitoring and Change Detection; Proceedings of Symposium HS3007 at IUGG 2007, Perugia, Italy, July 2007, IAHS Publication, 316, 149-156, 2007.

Kriegel, D., Mayer, C.,, Hagg, W., Vorogushyn, S., Duethmann, D., Gafurov, A., and Farinott, D.: Changes in glacierisation, climate and runoff in the second half of the 20th century in the Naryn basin, Central Asia, Global Planet. Change, 110, 51-61, 2013.

Kronenberg, M., Barandun, M., Hoelzle, M., Huss, M., Farinotti, D., Azisov, E., Usulbaiev, R., Gafurov, A., Petrakov, D., and Kääb, A.: Mass balance reconstruction fro Glacier 354, Tien Shan, from 2003-2014, Ann. Glaciol., 57, 92-102, 2016.

Kuhn, M.: Mass budget imbalances as a criterion for a climatic classification of glaciers, Geogr. Ann. A, 66, 229-238, 1984.

Kulkarni, A.: Mass balance of Himalyan glaciers using AAR and ELA methods, J. Glaciol., 38, 101-104, 1992.

Kutuzov, S. and Shahgedanova, M.: Changes in the extent of glaciers in the Eastern Terskey Alatoo, the Central Tien-Shan, in reponse to climatic fluctuations in between the end of 19th and the beginning of the 21 st century, Global Planet. Change, 69, 59-70, 2009.

Machguth, H., Paul, F., Hoelzle, M., and Haeberli, W.: Distributed glacier mass balance modelling as an important component of modern multi-level glacier monitoring, Ann. Glaciol., 43, 335343, 2006.

Martinec, J. and Rango, A.: Areal distribution of snow waterequivalent evaluated by snow cover monitoring, Water Resour. Res., 17, 1480-1488, 1981.

Mercanton, P.: Vermessungen am Rhonegletscher, Mensurations au Glacier du Rhone, 1874-1915, Neue Denkschriften der Schweizerischen Naturforschenden Gesellschaft, Kommissions-Verlag von Georg \& Co., Basel/Genf/Lyon, 1916.

Narama, C., Kääb, A., Duishonakunov, M., and Abdrakhmatov, K.: Spatial variability of recent glacier changes in the Tien Shan Mountains, Central Asia Corona (1970), Landsat (2000), and ALOS (2007) satellite data, Global Planet. Change, 71, 42-54, 2010.

Neckel, N., Kropacek, J., Bolch, T., and Hochschild, V.: Glaciermass changes on the Tibetan Plateau 2003-2009 derived from ICESat laser altimetry measurements, Environ. Res. Lett., 9, 014009, https://doi.org/10.1088/1748-9326/9/1/014009, 2014.

Niederer, P., Bilenko, V., Ershova, N., Hurni, H., Yerokhin, S., and Maselli, D.: Tracing glacier wastage in the Northern Tien Shan (Kyrgyzstan/Central Asia) over the last 40 years, Climatic Change, 86, 227-234, 2007.

Nussbaumer, S. U., Hoelzle, M., Hüsler, F., Huggel, C., Salzmann, N., and Zemp, M.: Glacier Monitoring and Capacity Building: Important Ingredients for Sustainable Mountain Development, Mt. Res. Dev., 37, 141-152, 2017.

Nuth, C. and Kääb, A.: Co-registration and bias corrections of satellite elevation data sets for quantifying glacier thickness change, The Cryosphere, 5, 271-290, https://doi.org/10.5194/tc-5-2712011, 2011.

Nye, J.: The response of glaciers and ice-sheets to seasonal and climatic changes, Proc. R. Soc. Lon. Ser.-A, 256, 559-584, 1960.

Ohmura, A., Kasser, P., and Funk, M.: Climate at the equilibrium line of glaciers, J. Glaciol., 38, 397-411, 1992.

Østrem, G., and Brugman, M.: Glacier mass-balance measurements: a manual for field and office work, NHRI Science Report. National Hydrology Research Institute, Inland Waters Directorate Conservation and Protection Environment Canada 11, Innovation Boulevard Saskatoon, Saskatchewan, Canada, 4, 224 pp., 1991.

Ozmonov, A., Bolch, T., Xi, C., Wei, J., and Kurban, A.: Glacier characteristics and changes in the Sary-Jaz river basin (Central Tien Shan) 1990-2010, Remote Sens. Lett., 4, 725-734, 2013.

Parajka, J. P., Haas, P., Kirnbauer, R., Jansa, J., and Blöschel, G.: Potential of time-lapse photography of snow for hydrological purposes at the small catchment scale, Hydrol. Process., 26, 33273337, 2012.

Paul, F.: Calculation of glacier elevation changes with SRTM: Is there an elevation dependent bias?, J. Glaciol., 55, 945-946, 2008.

Paul, F., Bolch, T., Kääb, A., Nagler, T., Nuth, C., Scharrer, K., Shepherd, A., Strozzi, T., Ticconid, F., Bhambri, R., Berthier, E., Bevan, S., Gourmelen, N., Heid, T., Jeong, S., Kunz, M., Lauknes, T., Luckman, A., Merryman Boncori, J., Moholdt, G., Muir, A., Neelmeijer, J., Rankl, M., VanLooy, J., and Van Niel, T.: The glaciers climate change initiative: Methods for creating glacier area, elevation change and velocity products, Remote Sens. Environ., 162, 408-426, https://doi.org/10.1016/j.rse.2013.07.043, 2013. 
Pertziger, F.: Abramov Glacier Data Reference Bood: Climate, Runoff, Mass Balance, Munich Technical University, Munich, 1996.

Petrakov, D., Shpuntova, A., Aleinikov, A., Kääb, A., Kutuzov, S., Lavrentiev, I., Stoffel, M., Tutubalina, O., and Usulbajev, R.: Accelerated glacier shrinkage in the Ak-Shyirak massif, Inner Tien Shan, during 2003 to 2013, Sci. Total Environ., 562, 364-378, 2016.

Pieczonka, T. and Bolch, T.: Region-wide glacier mass budgets and area changes for the Central Tien Shan between 1975 and 1999 using Hexagon KH-9 imagery, Global Planet. Change, 128, 113, 2015.

Pieczonka, T., Bolch, T., and Buchroithner, M.: Generation and evaluation of multitemporal digital terrain models of the Mt. Everest area from different optical sensors, ISPRS J. Photogramm., 66, 927-940, 2011.

Pieczonka, T., Bolch, T., Wei, J., and Liu, S.: Heterogeneous mass loss of glaciers in the Aksu-Tarim catchment (Central Tien Shan) revealed by $1976 \mathrm{KH}-9$ Hexagon and 2009 SPOT-5 stereo imagery, Remote Sens. Environ., 130, 233-244, 2013.

Rabatel, A., Dedieu, J., and Vincent, C.: Using remote-sensing data to determine equilibrium-line altitude and mass-balance series: validation on three French glaciers, 1994-2002, J. Glaciol., 51, 539-546, 2005

Rabatel, A., Dedieu, J., Thibert, E., Letréguilly, A., and Vincent, C.: 25 years (1981-2005) of equilibrium-line altitude and mass balance reconstruction on Glacier Blanc, French Alps, using remote-sensing methods and meteorological data, J. Glaciol., 54, 307-314, 2008.

Rabatel, A., Dedieu, J., Bermejo, A., Loarte, E., Soruco, A., Gomez, J., Leonardini, G., Vincent, C., and Sicart, J.: Can the snowline be used as an indicator of the equilibrium line and mass balance for glaciers in the outer tropics?, J. Glaciol., 58, 10271036. https://doi.org/10.3189/2012JoG12J027, 2012.

Rabatel, A., Letréguilly, A., Dedieu, J.-P., and Eckert, N.: Changes in glacier equilibrium-line altitude in the western Alps from 1984 to 2010: evaluation by remote sensing and modeling of the morpho-topographic and climate controls, The Cryosphere, 7, 1455-1471, https://doi.org/10.5194/tc-7-1455-2013, 2013.

Rasmussen, L.: Meteorological controls on glacier mass balance in High Asia, Ann. Glaciol., 54, 352-359, 2013.

Salzmann, N., Huggel, C., Rohrer, M., Silverio, W., Mark, B. G., Burns, P., and Portocarrero, C.: Glacier changes and climate trends derived from multiple sources in the data scarce Cordillera Vilcanota region, southern Peruvian Andes, The Cryosphere, 7, 103-118, https://doi.org/10.5194/tc-7-103-2013, 2013.

Schaper, J., Martinec, J., and Seidel, K.: Distributed mapping of snow and glaciers for improved runoff modelling, Hydrol. Process., 13, 2023-2031, 1999.

Schär, C., Vasilina, L., Pertziger, F., and Dirren, S.: Seasonal runoff forecasting using precipitation from meteorological data assimilation systems, J. Hydrometeorol., 5, 959-973, 2004.

Schienmann, R., Lüthi, D., Vidale, P. L., and Schär, C.: The precipitation climate of Central Asia - intercomparision of observational and numerical data sources in a remote semiarid region, Int. J. Climatol., 28, 295-314, 2008.

Schmidli, J., Frei, C., and Schä, C.: Reconstruction of mesoscale precipitation fields from sparse observations in complex terrain, J. Climate, 14, 3289-3306, 2001.
Schöne, T., Zech, C., Unger-Shayesteh, K., Rudenko, V., Thoss, H., Wetzel, H.-U., and Zubovich, A.: A new permanent multiparameter monitoring network in Central Asian high mountains - from measurements to data bases, Geosci. Instrum. Meth., 2, 97-111, https://doi.org/10.5194/gi-2-97-2013, 2013.

Semakova, E., Gunasekara, K., and Semakov, D.: Identification of the glaciers and mountain naturally dammed lakes in the Pskem, the Kashkadarya and the Surhandarya River basins, Uzbekistan, using ALOS satellite data, Geomatics, Nat. Hazards Risk, 7, 1081-109, 2016.

Siegfried, T., Bernauer, T., Guiennet, R., Sellars, S., Robertson, A., Mankin, J., Bauer-Gottwein, P., and Yakovlev, A.: Will climate change exacerbate water stress in Central Asia?, Climatic Change, 112, 881-899, https://doi.org/10.1007/s10584011-0253-z, 2012.

Sold, L., Huss, M., Hoelzle, M., Andereggen, H., Joerg, P., and Zemp, M.: Methodological approaches to infer end-of-winter snow distribution on alpine glaciers, J. Glaciol., 59, 1047-1059, 2013.

Sold, L., Huss, M., Eichler, A., Schwikowski, M., and Hoelzle, M.: Unlocking annual firn layer water equivalents from groundpenetrating radar data on an Alpine glacier, The Cryosphere, 9, 1075-1087, https://doi.org/10.5194/tc-9-1075-2015, 2015.

Sorg, A., Bolch, T., Stoffel, M., Solomina, O., and Beniston, M.: Climate change imapcts on glaciers and runoff in Central Asia, Nat. Clim. Change 2, 725-731, https://doi.org/10.1038/nclimate1592, 2012.

Stumm, D.: The mass balance of selected glaciers of the Southern Alps in New Zealand, PhD thesis, Department of Geography, University of Otago, Dunedin, New Zealand, 283 pp., 2011.

Surazakov, A. and Aizen, V.: Estimating volume change of mountain glaciers using SRTM and map-based topographic data, IEEE Geosci. Remote S., 44, 2991-2995, 2006.

Suslov, V. and Akbarov, A.: Hydrological regime of glaciers in the Alay Range, Central Asia, in: Symposium on the Hydrology of Glaciers, Cambridge, UK, 1969, vol. 95, 235-238, International Union of Geodesy and Geophysics International Association of Scientific Hydrology Commission of Snow and Ice, 1973.

Suslov, V. and Krenke, A.: Lednik Abramov, Hydromet Publishing, St. Petersburg, Russia, 1980.

Thibert, E. and Vincent, C.: Best possible estimation of mass balance combining glaciological and geodetic methods, Ann. Glaciol., 50, 112-118, 2009.

Thibert, E., Vincent, C., Blanc, R., and Eckert, N.: Glaciological and volumetric mass balance measurements: an error analysis over 51 years, Sarennes glacier, French Alps, J. Glaciol., 50, 522-532, 2008.

Unger-Shayesteh, K., Vorogushyn, S., Farinotti, D., Gafurov, A., Duethmann, D., Mandychev, A., and Merz, B.: What do we know about past changes in the water cycle of Central Asian headwaters? A review, Global Planet. Change, 110, 4-25, 2013.

Ushnurtsev, S.: Mass balance fluctuations of the Sary-Tor glacier in inner Tien Shan and its reconstruction for the period 1930-1988, Data Glaciol. Stud., 71, 70-79, 1991.

Voloshina, A.: Climate and meteorological features of glacier covered area in the Akshiirak massif, Data Glaciol. Stud., 62, 184 193, 1988.

Wang, P., Li, Z., Li, H., Wang, W., and Yao, H.: Comparison of glaciological and geodetic mass balance at Urumqi glacier no. 
1, Tian Shan, Central Asia, Global Planet. Change, 114, 14-22, 2014.

WGMS: Fluctuations of Glaciers 1985-1990, vol. VI of Fluctuations of Glaciers, IAHS (ICSI), UNEP, UNESCO, Zürich, Switzerland, 1993.

WGMS: Glacier Mass Balance Bulletin no. 6, vol. 6 of Glacier Mass Balance Bulletin, IAHS(ICSI)/UNEP/UNESCO/WMO, World Glacier Monitoring Service, Zürich, Switzerland, 2001.

WGMS: Glacier mass balance bulletin no. 12, vol. 12 of Glacier Mass Balance Bulletin, ICSU (WDS)/IUGG(IACS)/UNEP/UNESCO/WMO, World Glacier Monitoring Service, Zürich, Switzerland, https://doi.org/10.5904/wgms-fog-2013-11, 2013.

WGMS: Fluctuations of Glaciers Database, World Glacier Monitoring Service, Zurich, Switzerland, https://doi.org/10.5904/wgmsfog-2017-06, 2017.

WMO: GCOS/GTOS Plan for Terrestrial Climate Related Observations, vol. 796, World Meteorological Organization, Geneva, Switzerland, 1997a.

WMO: GHOST Global Hierarchical Observing Strategy, vol. 862, World Meteorological Organization, Geneva, Switzerland, 1997b.

WMO: Implementation Plan for the Global Observing System for Climate in Support of the UNFCCC (2010 update), vol. 1523, World Meteorological Organization, Geneva, Switzerland, 2010.
Yemelyanov, Y.: Accumulation, ablation and run-off on Lednik Abramov (Alay range, USSR), in: Symposium on the hydrology of glaciers, Cambridge, UK, 1969, vol. 95, p. 239, International Union of Geodesy and Geophysics International Association of Scientific Hydrology Commission of Snow and Ice, 1973.

Zemp, M., Thibert, E., Huss, M., Stumm, D., Rolstad Denby, C., Nuth, C., Nussbaumer, S. U., Moholdt, G., Mercer, A., Mayer, C., Joerg, P. C., Jansson, P., Hynek, B., Fischer, A., Escher-Vetter, H., Elvehøy, H., and Andreassen, L. M.: Reanalysing glacier mass balance measurement series, The Cryosphere, 7, 12271245, https://doi.org/10.5194/tc-7-1227-2013, 2013.

Zemp, M., Frey, H., Gärtner-Roer, I., Nussbaumer, S., Hoelzle, M., Paul, F., Haeberli, W., Denzinger, F., Ahlström, A., Anderson, B., Bajracharya, S., Baroni, C., Braun, L., Caceres, B., Casassa, G., Cobos, G., Davila, L., Delgado Granados, H., Demuth, M., Espizua, L., Fischer, A., Fuijita, K., Gadek, B., Ghazanfar, A., Hagen, J., Holmlund, P., Karimi, N., Li, Z., Pelto, M., Pitte, P., Popovnin, V., Portocarrero, C., Prinz, R., Sangewar, C., Severskiy, I., Sigurdsson, O., Soruco, A., Usulbajev, R., and Vincent, C.: Historically unprecedented global glacier decline in the early 21 st century, J. Glaciol., 61, 745-762, 2015. 